\title{
Thermodynamics and Mechanism of Protonated Asparagine Decomposition
}

\author{
Amy L. Heaton and Peter B. Armentrout \\ Department of Chemistry, University of Utah, Salt Lake City, Utah, USA
}

Deamidation of the amino acid asparagine (Asn) is a primary route for spontaneous posttranslational protein modification biologically and is a $\mathrm{pH}$ dependent process. Here we present a full molecular description of the deamidation and $\left(\mathrm{H}_{2} \mathrm{O}+\mathrm{CO}\right)$ loss reactions of protonated asparagine, $\mathrm{H}^{+}(\mathrm{Asn})$, by studying its collision-induced dissociation (CID) with Xe using a guided ion beam (GIB) tandem mass spectrometer. Analysis of the kinetic energy-dependent CID cross sections provides the $0 \mathrm{~K}$ barriers for the deamidation and $\left(\mathrm{H}_{2} \mathrm{O}+\mathrm{CO}\right)$ loss reactions after accounting for unimolecular decay rates, internal energy of reactant ions, multiple ion-molecule collisions, and competition among the decay channels. Relaxed potential energy surface scans performed at the B3LYP/6-31G(d) level identify the transition-state (TS) and intermediate reaction species for these processes, structures that are further optimized at the B3LYP/6-311+G(d,p) level. Intrinsic reaction coordinate (IRC) calculations are also performed at this level on the rate-limiting reaction TSs to validate the molecular details and energy dependence of these species. Single point energies of the key optimized TSs and intermediates are calculated at B3LYP, B3P86, and MP2(full) levels using a 6-311+G(2d,2p) basis set. A number of alternative high-energy mechanisms for $\left(\mathrm{H}_{2} \mathrm{O}+\mathrm{CO}\right)$ loss from $\mathrm{H}^{+}$(Asn) are also investigated. Combining both experimental work and quantum chemical calculations allows for a complete characterization of the elementary steps of these reactions as well as a comprehensive evaluation of the complex behavior of the deamidation reaction. (J Am Soc Mass Spectrom 2009, 20, 852-866) (c) 2009 American Society for Mass Spectrometry

$\mathrm{D}$ eamidation at amide residues (asparagine and glutamine) is a dominant pathway for protein degradation. The chemical instability of amide residues in proteins has been postulated as their central biological role, serving as "clocks" for the regulation of biological processes [1]. Yet this instability has damaging time-dependent effects and has been identified as a root cause of human aging [2]. Furthermore, the process of protein deamidation may play a key role in a number of aggregation diseases including Alzheimer's disease $[3,4]$ and Parkinson's disease [5].

Solution phase studies have been used to investigate the rate and general mechanism of amide deamidation in asparaginyl (Asn) residues. Here the deamidation reaction is known to result in formation of a stable succinimide ring structure, and reaction rates for this transformation have been experimentally characterized as a function of solution conditions [6-11] as well as protein structure $[5,8]$. O'Connor and coworkers [1214] have additionally used electron capture dissociation to analyze the abundance of deamidation products from the solution-phase deamidation reaction. Yet all studies on asparagine deamidation in solution are dependent on temperature, $\mathrm{pH}[6,9-11]$, viscosity $[8,9]$, and higher-

Address reprint requests to Dr. P. B. Armentrout, Department of Chemistry, University of Utah, 315 S. 1400 E., Rm 2020, Salt Lake City, UT 84112, USA. E-mail: armentrout@chem.utah.edu order protein structural characteristics $[5,8]$, which complicate the interpretation of these studies such that an experimental investigation of the precise series of molecular interactions needed for the decomposition is unfeasible. Computational studies by Konuklar et al. [6] have investigated the mechanism of ring formation in a model peptide using the B3LYP /6-31G* level of theory including characterization as a function of $\mathrm{pH}$ with a polarized continuum model. The potential energy surface was modeled as a stepwise process, where the first step involves cyclization and the second step involves the departure of ammonia. In acidic media, theory suggests that the rate-limiting step of deamidation involves formation of the succinimide ring, whereas in basic media, the ratelimiting step involves departure of the $\mathrm{NH}_{3}$ leaving group. Although these quantum chemical calculations provide insightful characterizations of molecular reactivity, they are difficult to quantitatively correlate to solution-phase experimental results.

An alternative means used to study such transformations is by measurement of analogous decompositions in the gas phase. Techniques in mass spectrometry are emerging as useful methods for the characterization of biological systems. Among these, threshold collisioninduced dissociation (TCID) experiments using tandem mass spectrometry provide rigorous thermodynamic information that reflects the intrinsic bond strengths and molecular transformation energies for a reaction. 
Furthermore, these results can be directly and quantitatively compared with theoretical results, which allow for a complete characterization of the elementary steps undergone in a reaction. Deamidation in the $\mathrm{Na}^{+}$(Asn) complex has recently been comprehensively investigated by these methods [15], and these results are compared with those of the present study below. Combined, the $\mathrm{Na}^{+}$(Asn) and $\mathrm{H}^{+}$(Asn) systems provide an ideal starting point for a comprehensive analysis of asparagine deamidation. Indeed, a thorough characterization of $\mathrm{H}^{+}$(Asn) deamidation sets the groundwork for further studies aimed at addressing subsequent factors that influence this reaction in biological systems including a nucleophilic additionelimination step that involves a peptidic nitrogen rather than the acidic $\mathrm{OH}$ group, steric and energetic effects of the C-terminal residue side-chains, and higher-order structural considerations.

In addition to deamidation, another fragmentation process observed in the low-energy metastable ion fragmentation of protonated asparagine [16, 17], as well as many other protonated amino acids and peptides, is loss of $\mathrm{CH}_{2} \mathrm{O}_{2}$. Quantum chemical theory has been used to characterize multiple pathways for the analogous process in the simplest protonated amino acid, glycine $[18,19]$, small poly-glycyl peptides $[19,20]$, and other protonated amino acids [17], finding that the most thermodynamically and kinetically favored mechanism involves loss of $\mathrm{H}_{2} \mathrm{O}+\mathrm{CO}$. Quantitative experimental characterizations of this process are limited to these small glycyl systems [19, 20].

Here, we comprehensively characterize the deamidation and $\left(\mathrm{H}_{2} \mathrm{O}+\mathrm{CO}\right)$ loss reactions of $\mathrm{H}^{+}$(Asn). Complications resulting from solvent effects are removed by using gas-phase TCID experiments carried out in a guided ion beam (GIB) tandem mass spectrometer. We measure the first absolute experimental energetics for the observed reactions and use theoretical calculations at the B3LYP/6-311+G(d,p) level to provide structures, vibrational frequencies, and rotational constants needed for analysis of the experimental cross sections. Experimental threshold energies are compared with theoretical calculations performed at the B3LYP, B3P86, and MP2(full) levels using a 6-311+G(2d,2p) basis set to fully characterize the rate-limiting elementary steps for the deamidation and $\left(\mathrm{H}_{2} \mathrm{O}+\mathrm{CO}\right)$ loss reactions. In addition, the theoretical calculations provide detailed step-by-step pathways for these processes as well as for a number of alternative high-energy pathways for comparison.

\section{Experimental and Computational}

\section{General Experimental Procedures}

Cross sections for CID of the $\mathrm{H}^{+}$(Asn) complex are measured using a guided ion beam tandem mass spectrometer that has been described in detail previously $[21,22]$. Ions are generated using an electrospray ionization (ESI) source [23] under conditions similar to those described elsewhere [23-26]. Briefly, the ESI is operated using a $50: 50$ by volume $\mathrm{H}_{2} \mathrm{O} / \mathrm{MeOH}$ solution with $\sim 10^{-4} \mathrm{M}$ Asn (all chemicals purchased from Sigma-Aldrich, St. Louis, MO, USA), syringe-pumped at a rate of $0.04 \mathrm{~mL} / \mathrm{h}$ into a 35 gauge stainless steel needle biased at $\sim 2000 \mathrm{~V}$. Ionization occurs over the $\sim 5$ $\mathrm{mm}$ distance from the tip of the needle to the entrance of the capillary, biased at $\sim 35 \mathrm{~V}$. Ions are directed by a capillary heated to $80^{\circ} \mathrm{C}$ into a radio frequency (rf) ion funnel [27], wherein they are focused into a tight beam. Ions exit the ion funnel and enter an $\mathrm{rf}$ hexapole ion guide that traps them radially. Here the ions undergo multiple collisions $\left(>10^{4}\right)$ with the ambient gas and become thermalized. Ions produced in the source are assumed to have internal energies well described by a Maxwell-Boltzmann distribution of rovibrational states at $300 \mathrm{~K}$, as characterized in previous experiments [15, 23, 25, 26, 28-30].

The $\mathrm{H}^{+}$(Asn) complex is extracted from the source and mass selected using a magnetic momentum analyzer. The mass-selected $\mathrm{H}^{+}$(Asn) ions are decelerated to a well-defined kinetic energy and are focused into a rf octopole ion guide that traps the ions radially [31, 32]. The ion guide minimizes losses of the reactant and any product ions resulting from scattering. The octopole passes through a static gas cell containing xenon, which is used as the collision gas for reasons described elsewhere $[33,34]$. After collision, the reactant and product ions drift to the end of the octopole where they are extracted and focused into a quadrupole mass filter for mass analysis. The ions are detected with a high voltage dynode, scintillation ion detector [35] and the signal is processed using standard pulse counting techniques.

Ion intensities, measured as a function of collision energy, are converted to absolute cross sections as described previously [21]. Product branching ratios are calculated from the absolute cross sections. The uncertainty in these relative cross sections is about $\pm 5 \%$ and that for the absolute cross sections is about $\pm 20 \%$. The ion kinetic energy distribution is measured to be Gaussian and has a typical FWHM of 0.1 to $0.2 \mathrm{eV}$ (lab). Uncertainties in the absolute energy scale are about $\pm 0.05 \mathrm{eV}$ (lab). Ion kinetic energies in the laboratory (lab) frame are converted to energies in the center-ofmass $(\mathrm{CM})$ frame using $E_{C M}=E_{l a b} m /(m+M)$, where $M$ and $m$ are the masses of the ionic and neutral reactants, respectively. All energies herein are reported in the CM frame unless otherwise noted.

\section{Thermochemical Analysis}

Threshold regions of the CID reaction cross sections and product branching fractions are modeled using eq 1 ,

$$
\begin{aligned}
\sigma_{j}(E)= & \left(n \sigma_{0, j} / E\right) \sum g_{i} \int_{E_{0, j}-E_{i}}^{E}\left[k_{j}\left(E^{*}\right) / k_{t o t}\left(E^{*}\right)\right] \\
& \times\left\{1-e^{-k_{\text {tot }}\left(E^{*}\right)}\right\}(E-\varepsilon)^{n-1} d(\varepsilon)
\end{aligned}
$$

where $\sigma_{0, j}$ is an energy-independent scaling factor for channel $j, n$ is an adjustable parameter that describes the 
efficiency of collisional energy-transfer [22], $E$ is the relative kinetic energy of the reactants, $E_{0, j}$ is the threshold for dissociation of the ground electronic and rovibrational state of the reactant ion at $0 \mathrm{~K}$ for channel $j, \tau$ is the experimental time for dissociation $\left(\sim 5 \times 10^{-4} \mathrm{~s}\right.$ in the extended dual octopole configuration as measured by time-of-flight studies) [22], $\varepsilon$ is the energy transferred from translation during the collision, and $E^{*}$ is the internal energy of the energized molecule (EM) after the collision, i.e., $E^{*}=\varepsilon+E_{i}$. The summation is over the rovibrational states of the reactant ions, $i$, where $E_{i}$ is the excitation energy of each state and $g_{i}$ is the fractional population of those states $\left(\sum g_{i}=1\right)$. The BeyerSwinehart algorithm [36-38] is used to evaluate the number and density of the rovibrational states and the relative populations $g_{\mathrm{i}}$ are calculated for a MaxwellBoltzmann distribution at $300 \mathrm{~K}$. The term $k_{j}\left(E^{*}\right)$ is the unimolecular rate constant for dissociation of the energized molecule to channel $j$. The rate constants $k_{j}\left(E^{*}\right)$ and $k_{\mathrm{tot}}\left(E^{*}\right)$ are defined by Rice-Ramsperger-KasselMarcus (RRKM) theory as in eq $2[39,40]$,

$$
k_{\text {toot }}\left(E^{*}\right)=\sum_{j} k_{j}\left(E^{*}\right)=\sum_{j} d_{j} N_{j}^{\dagger}\left(E^{*}-E_{0, j}\right) / h \rho\left(E^{*}\right)
$$

where $d_{j}$ is the reaction degeneracy of channel $j, N^{+}{ }_{j}\left(E^{*}-\right.$ $\left.E_{0, j}\right)$ is the sum of rovibrational states of the transitionstate (TS) for channel $j$ at an energy $E^{*}-E_{0, j}$ and $\rho\left(E^{*}\right)$ is the density of states of the energized molecule (EM) at the available energy, $E^{*}$. These rate constants allow both kinetic shifts and competition between multiple parallel channels to be modeled [41, 42].

Several effects that obscure the interpretation of the data must be accounted for during data analysis to produce accurate thermodynamic information. The first effect involves energy broadening resulting from the thermal motion of the neutral collision gas and the kinetic energy distribution of the reactant ion. This is accounted for by explicitly convoluting the model over both kinetic energy distributions, as described elsewhere in detail [21]. The second effect considers that eq 1 only models cross sections that represent products formed as the result of a single collision event. To ensure rigorous single collision conditions, data are collected at three pressures of $\mathrm{Xe}$, generally about 0.12 , 0.08 , and 0.04 mTorr, and the resulting cross sections evaluated for pressure effects and extrapolated to zero pressure when necessary [43]. The third effect arises from the lifetime for dissociation, which leads to a delayed onset for the CID threshold, a kinetic shift, which becomes more noticeable as the size of the molecule increases. These kinetic shifts are estimated by the incorporation of RRKM theory as shown in eq 1 and as described in detail elsewhere [41]. To evaluate the rate constant in eq 1 , sets of rovibrational frequencies for the EM and all TSs are required and are taken from quantum chemical calculations detailed in the next section. The transitional frequencies for loose TSs are treated as rotors, a treatment that corresponds to a phase space limit (PSL), as described in detail elsewhere
[41, 42]. The 2D external rotations in these cases are treated adiabatically but with centrifugal effects included [38], and the adiabatic 2D rotational energy is treated using a statistical distribution with an explicit summation over all the possible values of the rotational quantum number [41, 42]. For reactions where a tight transition-state is required, all molecular parameters are taken from theoretical results. We additionally determine the entropy of activation for each dissociation channel as described in detail elsewhere [42]. These $\Delta S^{\ddagger}$ quantities, which are energy (or temperature) dependent, are tabulated at $1000 \mathrm{~K}$.

The model cross sections of eq 1 are convoluted with the kinetic energy distribution of the reactants [21] and compared to the data. A nonlinear least-squares analysis is used to provide optimized values for $\sigma_{0, j}, n$, and $E_{0, j}$. The uncertainty associated with $E_{0, j}$ is estimated from the range of threshold values determined from different datasets with variations in the parameter $n$, variations in vibrational frequencies $( \pm 10 \%)$, changes in $\tau$ by factors of 2 , and the uncertainty of the absolute energy scale, $0.05 \mathrm{eV}$ (lab). In deriving the final optimized reaction energies at $0 \mathrm{~K}$ for the loose TS reactions, we assume that the measured threshold $E_{0, j}$ values for dissociation are from ground state reactant to ground state ion and neutral reaction products. Given the relatively long experimental time frame $(\sim 5 \times$ $10^{-4} \mathrm{~s}$ ), dissociating products should be able to rearrange to their low-energy conformations after collisional excitation.

\section{Computational Details}

Model structures, vibrational frequencies, and energetics for all reaction species, including all transition-state and intermediate species, were calculated using Gaussian 03 [44]. To ensure that the ground state (GS) geometries of the reactant and product species of the $\mathrm{H}^{+}$(Asn) reactions were located, a simulated annealing methodology described previously [45] was used to explore conformational space. Optimizations of all lowlying structures found were performed at the B3LYP/ 6-311 $+\mathrm{G}(\mathrm{d}, \mathrm{p})$ level. A series of relaxed potential energy surface (PES) scans at the B3LYP/6-31G(d) level were performed to identify the elementary steps of the $\mathrm{H}^{+}$(Asn) deamidation and $\left(\mathrm{H}_{2} \mathrm{O}+\mathrm{CO}\right)$ loss reactions. Transition-state and intermediate structures occurring along the PESs were further optimized at the B3LYP/ $6-311+G(d, p)$ level, where it was verified that each transition-state contains one imaginary frequency and each intermediate is vibrationally stable. Each ratelimiting transition-state was further examined with an intrinsic reaction coordinate (IRC) calculation to verify that it connects the appropriate intermediates. Rotational constants were obtained from the optimized structures, and all vibrational frequencies were also calculated at this level. When used in internal energy determinations or for RRKM calculations, the vibrational frequencies were scaled by 0.99 [46]. Zero-point vibrational energy (ZPE) corrections were additionally determined using the scaled vibrational frequencies. 
Single point energies of all reactants, products, and key intermediates and transition states were determined at the B3LYP, B3P86, and MP2(full) levels using the $6-311+G(2 d, 2 p)$ basis set. Basis set superposition errors (BSSE) were estimated for loose transition-state (TS) reactions using the full counterpoise (cp) method [47, 48]. As for alkali metal cation systems [24, 49, 50], BSSE corrections for DFT calculations on $\mathrm{H}^{+}$(Asn) are small, 2.0 to $3.4 \mathrm{~kJ} / \mathrm{mol}$, whereas those for MP2 calculations are larger, here 8 to $14 \mathrm{~kJ} / \mathrm{mol}$. Feller and coworkers [51, 52], and Ohanessian and coworkers $[53,54]$ have previously commented that the full counterpoise approximation to BSSE for MP2 calculations can provide worse agreement with experiment than MP2 values without BSSE corrections. Because of this possibility for BSSE to overcorrect the MP2 calculations, both values are reported here. Clearly BSSE corrections are not appropriate for reactions limited by tight TSs.

\section{Results}

\section{Cross Sections for Collision-Induced Dissociation}

Kinetic energy dependent experimental cross sections were obtained for the interaction of Xe with $\mathrm{H}^{+}$(Asn). Figure 1 shows a representative dataset for the $\mathrm{H}^{+}$(Asn) system. Data shown are a mean of results taken at xenon pressures of $\sim 0.04,0.08$, and $0.12 \mathrm{mTorr}$, as no pressure dependence was detected within our experimental uncertainties. Eight major processes are observed in the $\mathrm{H}^{+}$(Asn) system $(133 \mathrm{~m} / \mathrm{z})$, and the proposed identity of each reaction product is provided in Scheme 1. (At higher energies, formation of 46 and 29 $\mathrm{m} / \mathrm{z}$ are also observed with apparent thresholds of about 6 and $7 \mathrm{eV}$, respectively, and maximum cross section magnitudes of 0.6 and $0.3 \AA^{2}$, respectively, at a collision energy of $8 \mathrm{eV}$. These products are likely to be

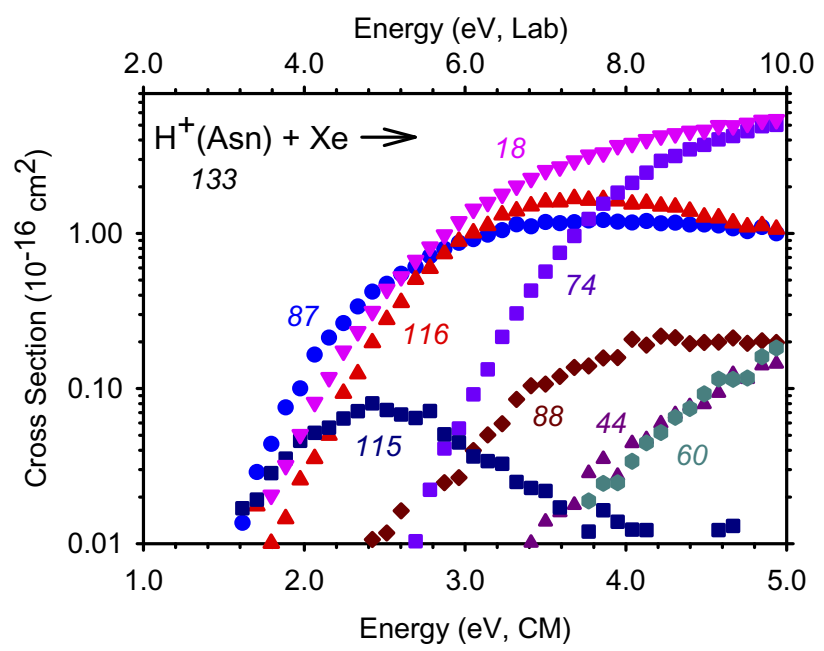

Figure 1. Cross sections for collision-induced dissociation of $\mathrm{H}^{+}$(Asn) with $\mathrm{Xe}$ as a function of kinetic energy in the center-ofmass frame (lower $x$-axis) and the laboratory frame (upper $x$-axis). Numbers indicate the mass to charge ratio of all ionic species.

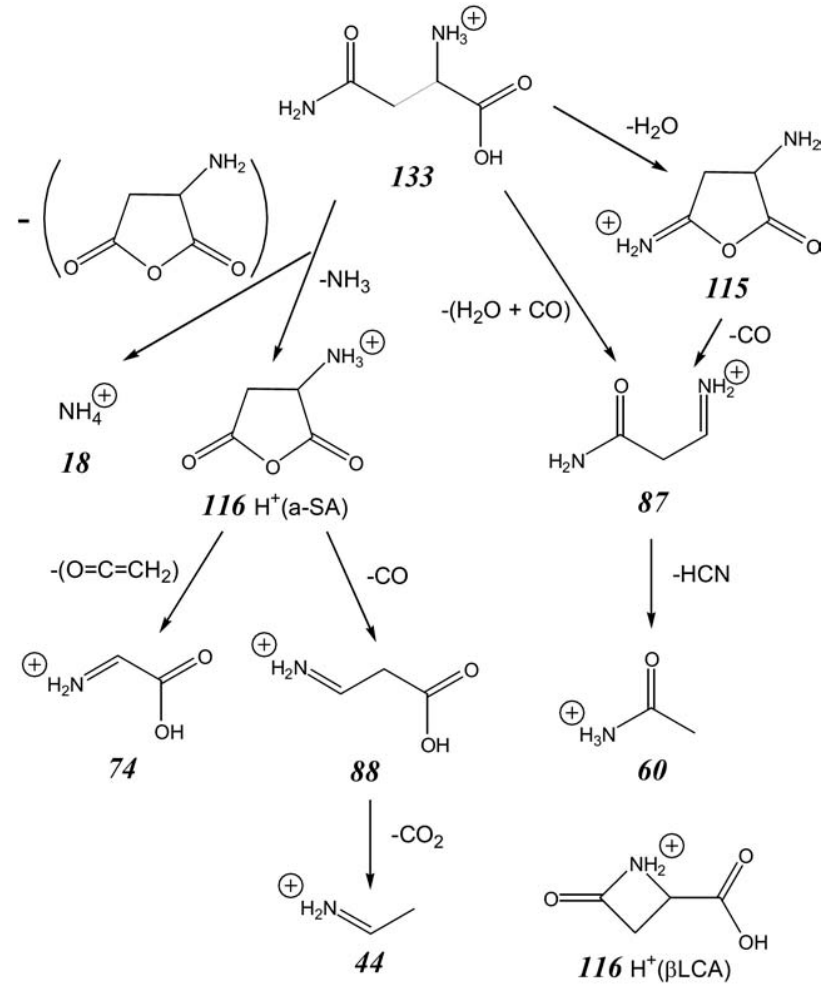

Scheme 1. Decomposition reaction pathways for $\mathrm{H}^{+}$(Asn) as observed in the CID cross section. Numbers indicate the mass to charge ratio of all ionic products. An alternate structure for the 116 product ion is shown in the lower right corner.

the result of sequential loss of $\mathrm{CO}$ and $\mathrm{NH}_{3}$ from the 74 $\mathrm{m} / z$ product ion yielding $\mathrm{CNOH}_{4}{ }^{+}$and $\mathrm{HCO}^{+}$.) Overall, there are only two major primary decomposition pathways for $\mathrm{H}^{+}$(Asn) observed here, deamidation and $\left(\mathrm{H}_{2} \mathrm{O}+\mathrm{CO}\right)$ loss. The 18 and $116 \mathrm{~m} / \mathrm{z}$ channels are the primary products of the deamidation reaction and can be seen to rise in parallel with increasing energy. The $116 \mathrm{~m} / \mathrm{z}$ ion, protonated 3-amino-succinic anhydride, $\mathrm{H}^{+}$(a-SA), Scheme 1, is the direct analogue of the succinic ring structure formed by deamidation of asparaginyl residues in peptides. The $18 \mathrm{~m} / \mathrm{z}$ ion is the protonated leaving group of deamidation, the ammonium ion, $\mathrm{NH}_{4}{ }^{+}$, with the neutral product being a-SA. Furthermore, the 74, 88, and $44 \mathrm{~m} / \mathrm{z}$ channels are all sequential dissociations of the primary $116 \mathrm{~m} / \mathrm{z}$ deamidation product. Here dissociations can occur by crossring cleavage to eliminate ketene, $\mathrm{O}=\mathrm{C}=\mathrm{CH}_{2}$ (74), or by loss of $\mathrm{CO}$ (88) followed by $\mathrm{CO}_{2}$ (44). Clearly, ketene elimination dominates, eventually depleting the $116 \mathrm{~m} / \mathrm{z}$ product ion at high energies. Indeed, the sum of the 116 and 74 cross sections parallels the 18 cross section throughout the energy range examined. In addition to deamidation, an alternate reaction pathway forms the $87 \mathrm{~m} / \mathrm{z}$ product, resulting from $\left(\mathrm{H}_{2} \mathrm{O}+\mathrm{CO}\right)$ loss from $\mathrm{H}^{+}$(Asn), which is coupled with the $\mathrm{H}_{2} \mathrm{O}$ loss channel, $115 \mathrm{~m} / \mathrm{z}$. The $60 \mathrm{~m} / \mathrm{z}$ product results from sequential dissociation of the primary $87 \mathrm{~m} / \mathrm{z}$ ion by loss of HCN.

As noted above, the decomposition reactions of $\mathrm{H}^{+}$(Asn) have been investigated by Dookeran et al. [16] 

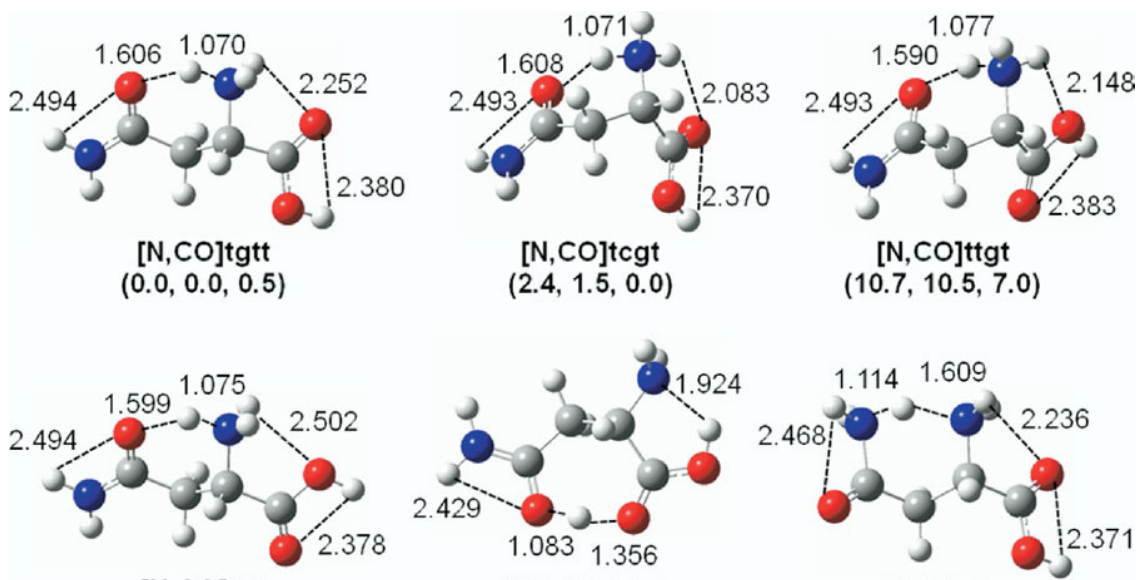

$[\mathrm{N}, \mathrm{CO}] \mathrm{tttt}$

$(11.5,12.8,11.5)$

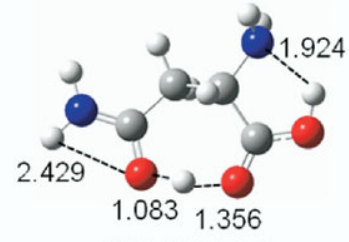

$[\mathrm{CO}, \mathrm{CO}] \mathrm{ctgt}$

$(30.1,24.5,38.7)$

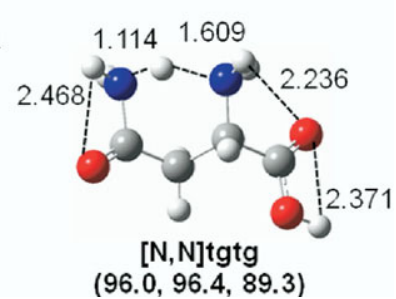

$(96.0,96.4,89.3)$

Figure 2. $\mathrm{H}^{+}$(Asn) low-energy conformers and alternate protonation site structures calculated at the B3LYP / 6-311+G(d,p) level. Hydrogen bond lengths are shown in Å. Energies $(\mathrm{kJ} / \mathrm{mol})$ from Table 1 are indicated at the B3LYP, B3P86, and MP2(full) levels of theory.

and by Rogalewicz et al. [17]. Dookeran et al. [16] examined the fragmentation as a function of cone voltage, whereas Rogalewicz et al. [17] used a triple quad to examine the collision-induced dissociation of protonated $\alpha$-amino acids with $\mathrm{Ar}$ at $12 \mathrm{eV}$ lab energy ( $2.8 \mathrm{eV}$ center of mass energy) under multiple collision conditions. In these works, the sources generate hot ions and the absolute energy scale is not well calibrated, such that the zero of energy differs from that in the present study. In both studies, the reaction channels observed in the metastable ion fragmentation of $\mathrm{H}^{+}$(Asn) are 116, 74, and 88 (deamidation followed by sequential ketene or $\mathrm{CO}$ elimination), and 115 and 87 (the coupled $\mathrm{H}_{2} \mathrm{O}+\mathrm{CO}$ loss products). Dookeran et al. do not observe 88 and Rogalewicz et al. do not observe 115. Neither study reports the ammonium ion 18 produced in the deamidation reaction, nor the other sequential channels observed here, 60 and 44 (the latter presumably because of their relatively small intensities). The behavior of the reaction channels as a function of cone voltage in the study of Dookeran et al. (plotted as a function of $\%$ of fragment ion abundance) is qualitatively consistent with the energy dependence of the data collected here, particularly the sequential character of 116 and 74 .

\section{Theoretical Results for Low-Energy $H^{+}$(Asn) Conformers}

Several low-energy conformations are possible for $\mathrm{H}^{+}$(Asn). The structures and energies of the lowestenergy conformers found using the simulated annealing methodology [45] along with alternative protonation sites are provided in Figure 2 and Table $1 . \mathrm{H}^{+}$(Asn) low-energy conformers are named by their protonation sites (in brackets) and by the series of dihedral angles starting from the carboxylic acid hydrogen of the backbone to the terminal R-group nitrogen. The dihedral angles are distinguished as cis (c, for angles between $\left.0^{\circ}-45^{\circ}\right)$, gauche $\left(\mathrm{g}, 45^{\circ}-135^{\circ}\right)$, or trans $\left(\mathrm{t}, 135^{\circ}-180^{\circ}\right)$. The four lowest energy structures of $\mathrm{H}^{+}$(Asn) lie within 13 $\mathrm{kJ} / \mathrm{mol}$ at all levels of theory. Each protonates at the amino nitrogen of the backbone and hydrogen bonds with the carbonyl oxygen of the side-chain, [N,CO]. The GS conformation determined by DFT methods orients the carbon chain in a trans $\angle C C C C$ dihedral arrangement (tgtt), whereas the MP2(full) calculations designate the conformer with a gauche $\angle C C C C$ dihedral arrangement (tcgt) as the GS. At all levels of theory considered, the energy differences between these two conformers are small. The lowest-energy structures also vary by the orientation of the dihedral $\angle O C C C$ angle, with the gauche (tgtt), cis (tcgt), and trans (ttgt and tttt) orientations lying $0-1,0-3,7-11$, and $11-13 \mathrm{~kJ} / \mathrm{mol}$ above the GS, respectively. The lowest energy structures with alternative protonation sites have $[\mathrm{CO}, \mathrm{CO}]$

Table 1. Relative energies ( $\mathrm{kJ} / \mathrm{mol})$ of $\mathrm{H}^{+}(\mathrm{Asn})$ low-energy conformers and deamidation products ${ }^{\mathrm{a}}$

\begin{tabular}{|c|c|c|c|}
\hline Structure & B3LYP & B3P86 & MP2(full) \\
\hline $\mathrm{H}^{+}$(Asn) $[\mathrm{N}, \mathrm{CO}] \mathrm{tg} t \mathrm{t}$ & 0.0 & 0.0 & 0.5 \\
\hline $\mathrm{H}^{+}$(Asn) $[\mathrm{N}, \mathrm{CO}] \mathrm{tcgt}$ & 2.4 & 1.5 & 0.0 \\
\hline $\mathrm{H}^{+}($Asn $)[\mathrm{N}, \mathrm{CO}] \mathrm{ttgt}$ & 10.7 & 10.5 & 7.0 \\
\hline $\mathrm{H}^{+}$(Asn) $[\mathrm{N}, \mathrm{CO}] \mathrm{tttt}\left(\mathrm{INT} 1_{\mathrm{O}}\right)$ & 11.5 & 12.8 & 11.5 \\
\hline $\mathrm{H}^{+}$(Asn) $[\mathrm{CO}, \mathrm{CO}] \mathrm{ctgt}$ & 30.1 & 24.5 & 38.7 \\
\hline $\mathrm{H}^{+}$(Asn) $[\mathrm{N}, \mathrm{CO}] \mathrm{cgtt}\left(\mathrm{INT} 1_{\mathrm{N}}\right)$ & 36.1 & 36.6 & 37.2 \\
\hline $\mathrm{H}^{+}$(Asn) $[\mathrm{CO}, \mathrm{CO}]$ cggt $\left(\mathrm{INT} 2_{\mathrm{N}}\right)$ & 42.3 & 38.7 & 45.0 \\
\hline $\mathrm{H}^{+}$(Asn) $[\mathrm{N}, \mathrm{N}] \operatorname{tg} \operatorname{tg}$ & 96.0 & 96.4 & 89.3 \\
\hline $\mathrm{H}^{+}$(Asn) $[\mathrm{N}, \mathrm{CO}] \operatorname{ctgg}\left(\mathrm{INT} 3_{\mathrm{N}}\right)$ & 104.1 & 104.4 & 102.4 \\
\hline $\mathrm{TS}_{\mathrm{N}}$ & 162.3 & 171.4 & 159.8 \\
\hline $\mathrm{NH}_{4}^{+}+\mathrm{a}-\mathrm{SA}$ & $146.7^{b}$ & $153.3^{b}$ & $152.6(139.0)^{b}$ \\
\hline $\mathrm{H}^{+}(\mathrm{a}-\mathrm{SA})+\mathrm{NH}_{3}$ & $167.7^{\mathrm{b}}$ & $176.1^{\mathrm{b}}$ & $173.4(165.3)^{\mathrm{b}}$ \\
\hline $\mathrm{H}^{+}(\beta \mathrm{LCA})+\mathrm{NH}_{3}$ & $197.6^{\mathrm{b}}$ & $210.5^{\mathrm{b}}$ & $206.1(198.2)^{b}$ \\
\hline
\end{tabular}

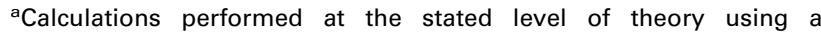
$6-311+G(2 d, 2 p)$ basis set with geometries calculated at B3LYP/6$311+G(d, p)$ level. Energies include ZPE corrections.

${ }^{b}$ Counterpoise corrected. 


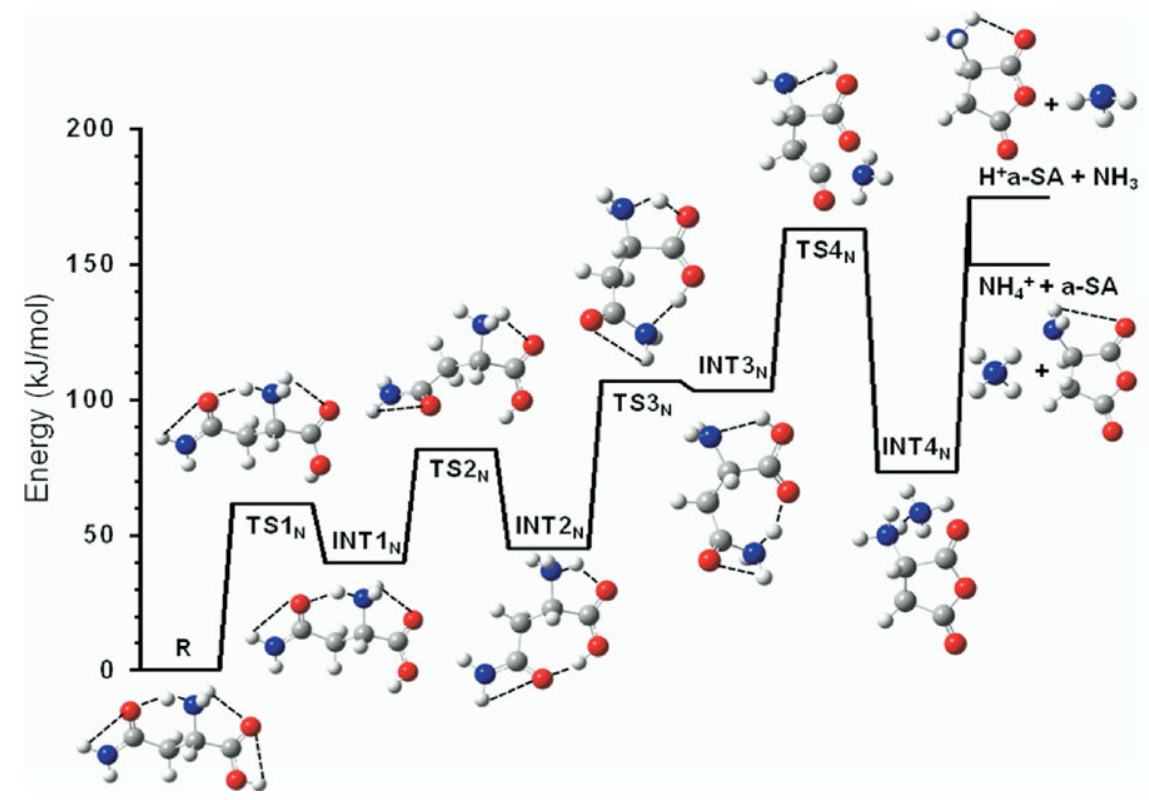

Figure 3. Reaction coordinate surface for $\mathrm{H}^{+}$(Asn) deamidation. Geometry optimizations and single point energies of each elementary step are determined at the B3LYP/6-311+G(d,p) level of theory and corrected for ZPE. Dashed lines indicate hydrogen bonds.

and $[\mathrm{N}, \mathrm{N}]$ binding (Figure 1) and lie 24-39 and 89-97 $\mathrm{kJ} / \mathrm{mol}$ above the GS, respectively (Table 1 ).

\section{Theoretical Results for $\mathrm{H}^{+}$(Asn) Deamidation}

In solution, the mechanism for deamidation of Asn is known to proceed by formation of cyclic succinic species [2-11], which corresponds to a-SA for the isolated amino acid [15]. As discussed further below, the mechanism elucidated here parallels that discovered for sodiated Asn [15], and furthermore, the theoretical energetics for the mechanism match experiment nicely (see below). For these reasons, alternative mechanisms for the deamidation reaction were not explored as thoroughly as in our previous work, although alternative decomposition products previously proposed in the literature [17] were examined, as discussed below, and extensive studies of conformational changes in the $\mathrm{H}^{+}$(Asn) system were explored. Such explorations should have revealed alternative low-energy decomposition pathways if they existed.

The potential energy surface of elementary steps leading to deamidation of $\mathrm{H}^{+}$(Asn) calculated at the B3LYP $/ 6-311+G(d, p)$ level of theory is provided in Figure 3. Relative energies of all species along this surface are provided in Table 2 and single point energies for the $\mathrm{H}^{+}$(Asn) deamidation products and several key intermediates are also included in Table 1. In Figure 3 , the GS of the reactant $\mathrm{H}^{+}$(Asn) complex (R) at the level of theory used here corresponds to $[\mathrm{N}, \mathrm{CO}] \operatorname{tgtt}$. In the first elementary step, the hydrogen bond of the backbone carboxylic acid group is broken by rotation of the $\angle$ HOCC dihedral angle from trans (R) to cis $\left(\mathrm{INT} 1_{\mathrm{N}}\right)$, which involves passing the gauche orientation

Table 2. Relative energies $(\mathrm{kJ} / \mathrm{mol})$ of intermediates, transition states, and products for $\mathrm{H}^{+}($Asn $)$decomposition ${ }^{\mathrm{a}}$

\begin{tabular}{|c|c|c|c|c|c|}
\hline \multicolumn{2}{|c|}{ Deamidation } & \multicolumn{2}{|c|}{$\left(\mathrm{H}_{2} \mathrm{O}+\mathrm{CO}\right)$ loss } & \multicolumn{2}{|c|}{ Seq $\mathrm{H}_{2} \mathrm{O}, \mathrm{CO}$ loss } \\
\hline Species & Energy & Species & Energy & Species & Energy \\
\hline $\mathrm{H}^{+}($Asn $)$ & 0.0 & $\mathrm{H}^{+}$(Asn) & 0.0 & & \\
\hline $\mathrm{TS} 1_{\mathrm{N}}$ & 61.4 & $\mathrm{TS} 1_{\mathrm{O}}$ & 17.1 & & \\
\hline $\mathrm{INT}_{\mathrm{N}}$ & 39.6 & INT1。 & 9.9 & & \\
\hline $\mathrm{TS}_{2} \mathrm{~N}$ & 81.7 & $\mathrm{TS}_{\mathrm{O}} \mathrm{O}$ & 151.7 & & \\
\hline $\mathrm{INT}_{\mathrm{N}}$ & 44.9 & INT2 O & 89.2 & INT2。' & 132.1 \\
\hline $\mathrm{TS}_{\mathrm{N}}$ & 106.6 & $\mathrm{TS}_{\mathrm{O}}$ & 129.5 & TS3o' & 181.2 \\
\hline INT3 $N$ & 103.4 & INT3O & 54.7 & INT4 ${ }^{\prime}$ & 116.7 \\
\hline $\mathrm{TS}_{\mathrm{N}}$ & 162.7 & INT4 & 71.1 & INT5。' & 101.9 \\
\hline INT4 $_{N}$ & 73.1 & $87+\mathrm{H}_{2} \mathrm{O}+\mathrm{CO}$ & 105.8 & & \\
\hline $\mathrm{NH}_{4}^{+}+\mathrm{a}-\mathrm{SA}$ & 150.0 & & & & \\
\hline $\mathrm{H}^{+}(\mathrm{a}-\mathrm{SA})+\mathrm{NH}_{3}$ & 174.8 & & & & \\
\hline
\end{tabular}

${ }^{a}$ Optimizations and single point calculations performed at the B3LYP/ 6-311+G(d,p) level of theory. Energies include ZPE corrections. Rate-limiting transition states are indicated by bold. 
of $\mathrm{TS}_{\mathrm{N}}$. In the second elementary step, a rotation of the $\angle$ CCCC dihedral angle from $168.8^{\circ}$ (trans) to $77.0^{\circ}$ (cis) reorients the carbon backbone such that the carbonyl oxygen of the side chain and the $\mathrm{OH}$ oxygen of the backbone carboxylic acid group can engage in a hydrogen bonding interaction. This $[\mathrm{CO}, \mathrm{CO}]$ cggt structure is comparable to $\mathrm{H}^{+}$(Asn)[CO,CO]ctgt, Figure 2, but with the $\angle$ HOCC dihedral angle in a gauche rather than a trans orientation (resulting in a $6-14 \mathrm{~kJ} / \mathrm{mol}$ energy increase from $[\mathrm{CO}, \mathrm{CO}]$ ctgt, Table 1$)$. In the third elementary step, rotation of the $\angle \mathrm{CCCO}$ dihedral angle of the side-chain breaks the $\mathrm{O}-\mathrm{H} \bullet \bullet \bullet \mathrm{O}$ hydrogen bond by passing $\mathrm{TS}_{\mathrm{N}}$. In this step, there are concerted proton transfers from the amino nitrogen of the backbone to the carbonyl oxygen of the backbone and from the $\mathrm{OH}$ oxygen of the backbone to the amide nitrogen of the side-chain to form $\mathrm{INT}_{\mathrm{N}_{\mathrm{N}}}$. The $\mathrm{INT}_{\mathrm{N}}$ structure is configured for ring closure, and in the fourth elementary step, the carbonyl oxygen of the backbone nears the carbon of the carboxamide functional group in a cyclization process. This leads to the rate-limiting $\mathrm{TS}_{\mathrm{N}}$, characterized by concerted ring-closure and ammonialoss. The free ammonia ligand then rearranges from $\mathrm{TS}_{\mathrm{N}}$ to associate favorably with the amino nitrogen of the newly formed $\mathrm{H}^{+}$(a-SA) moiety in INT4 $4_{\mathrm{N}}$. The last step of the deamidation reaction is the simple dissociation of this complex, which can form either $\mathrm{NH}_{4}{ }^{+}+$ a-SA or $\mathrm{H}^{+}(\mathrm{a}-\mathrm{SA})+\mathrm{NH}_{3}$. The former is calculated to lie 20-26 kJ/mol below the latter, Table 1, which reflects the calculated proton affinity difference between $\mathrm{NH}_{3}$ and a-SA. Overall, $\mathrm{NH}_{4}{ }^{+}$formation lies 7-18 kJ/mol below $\mathrm{TS}_{\mathrm{N}}$, whereas $\mathrm{H}^{+}$(a-SA) production lies 5-13 $\mathrm{kJ} / \mathrm{mol}$ above $\mathrm{TS}_{\mathrm{N}}$. It is important to note that even though $\mathrm{H}^{+}$(a-SA) $+\mathrm{NH}_{3}$ formation is calculated to lie higher than $\mathrm{TS}_{\mathrm{N}}$, the rate of dissociation for this channel is still primarily limited by $\mathrm{TS}_{\mathrm{N}}$ because modeling demonstrates that the number of accessible states for this tight TS is smaller than that for the loose PSL TS at the energies needed to observe this reaction channel (Figure 1). However, the loose PSL TS plays a key role in the branching between this pathway and the formation of $\mathrm{NH}_{4}{ }^{+}+$a-SA, as discussed further below.

As noted above, the computational study of Konuklar et al. [6] finds the rate-limiting step of deamidation of a model peptide in neutral and acidic media involves formation of the succinimide ring structure, with cleavage of the $\mathrm{C}-\mathrm{NH}_{3}$ bond and departure of the $\mathrm{NH}_{3}$ leaving group having a lower energy (although higher energy in basic media). In contrast to this stepwise mechanism, our theoretical results indicate that the rate-limiting TS for deamidation of $\mathrm{H}^{+}$(Asn) involves concerted motions of cyclization and $\mathrm{C}-\mathrm{NH}_{3}$ bond rupture.

In contrast to this mechanism, Rogalewicz et al. [17] suggested that deamidation of $\mathrm{H}^{+}$(Asn) produces the 4 -membered ring protonated $\beta$-lactam carboxylic acid $(\beta \mathrm{LCA})$, Scheme 1, primarily on the basis of analogies with more detailed calculations on the loss of ammonia from $\mathrm{H}^{+}$(Ser) and $\mathrm{H}^{+}$(Cys). Noncyclic deamidation products were estimated to be higher in energy. Computationally, the $\mathrm{H}^{+}(\beta \mathrm{LCA})$ product is found to lie 30-35 kJ/mol above protonated amino-succinic anhydride, $\mathrm{H}^{+}$(a-SA), Table 1 . As will be seen below, the agreement between the experimental threshold for formation of the $116+\mathrm{NH}_{3}$ channel agrees nicely with theory when 116 is identified as $\mathrm{H}^{+}$(a-SA), a result that rules out formation of $\mathrm{H}^{+}(\beta \mathrm{LCA})+\mathrm{NH}_{3}$. Further, $\mathrm{H}^{+}(\mathrm{a}-\mathrm{SA})$, like $\mathrm{H}^{+}(\beta \mathrm{LCA})$, has three exchangeable hydrogen atoms, consistent with the observations of Rogalewicz et al. [17].

As noted above, the experimental results indicate that the formation of 116 requires slightly more energy than formation of 18 , which is consistent with the calculated proton affinity difference between $\mathrm{NH}_{3}$ and a-SA $(\Delta \mathrm{PA}=20-26 \mathrm{~kJ} / \mathrm{mol})$. However, on the basis of an analogy to amino acids, one might have expected the PA for a-SA to be larger, rather than smaller, than that for ammonia. Indeed at the same three levels of theory used here, we calculate that PA(Gly) is $33-37 \mathrm{~kJ} / \mathrm{mol}$ higher than that for ammonia, and PA(Asn) is 83-94 $\mathrm{kJ} / \mathrm{mol}$ higher. This can be understood on the basis of the stability of the hydrogen bond between the protonated amino group and the carbonyl oxygen in all three protonated molecules. Calculations indicate that the groups adjacent to the carbonyl greatly alter the charge on the oxygen, from -0.51 in a-SA, which has the strongly resonant anhydride structure, to -0.55 for glycine, which has the hydroxyl group adjacent to the carbonyl, and to -0.66 for asparagine, which has the amide group in the side chain. Thus, the calculated $\mathrm{r}(\mathrm{NH} \bullet \bullet \bullet \mathrm{OC})$ bond lengths vary from 2.260 to 1.914 to $1.606 \AA$ (Figure 2), respectively, and the $\mathrm{r}(\mathrm{NH})$ bond lengths vary from 1.035 to 1.044 to $1.070 \AA$, respectively, compared to $1.026 \AA$ in $\mathrm{NH}_{4}{ }^{+}$.

\section{Theoretical Results for $\left(\mathrm{H}_{2} \mathrm{O}+\mathrm{CO}\right)$ Loss from $H^{+}$(Asn)}

The potential energy surface of elementary steps for $\left(\mathrm{H}_{2} \mathrm{O}+\mathrm{CO}\right)$ loss from $\mathrm{H}^{+}$(Asn) is provided in Figure 4, with the relative energies of all reaction species given in Table 2. In the first elementary step, the GS [N,CO]tgtt (R) conformer reorients to a $[\mathrm{N}, \mathrm{CO}] \mathrm{tttt}$ orientation in $\mathrm{INT}_{\mathrm{O}}$, by rotation of the backbone $\angle \mathrm{N}-\mathrm{C}-\mathrm{C}-\mathrm{OH}$ dihedral angle from $168.9^{\circ}$ to $10.6^{\circ}$. This conformer is set up for $\mathrm{H}_{2} \mathrm{O}$ loss by transfer of the amino hydrogen of the backbone to the carboxylic acid $\mathrm{OH}$ in the rate-limiting $\mathrm{TS}_{\mathrm{O}}$, which is stabilized by concerted ring closure. This elementary step results in formation of the 5-membered heterocyclic ring structure of INT2 ${ }_{\mathrm{O}}$ (the $115 \mathrm{~m} / \mathrm{z}$ product shown in Scheme 1). The stability of this intermediate is increased through binding to the $\mathrm{H}_{2} \mathrm{O}$ ligand, INT2 ${ }_{\mathrm{O}}$, by $42.9 \mathrm{~kJ} / \mathrm{mol}$ (at the B3LYP/6-311+G(d,p) level of theory) compared to INT2 ${ }_{\mathrm{O}}^{\prime}$, where the $\mathrm{H}_{2} \mathrm{O}$ ligand is lost in the reaction. The next elementary step proceeds by loss of $\mathrm{CO}$ from the ring via $\mathrm{TS} 3_{\mathrm{O}} \cdot \mathrm{TS}_{\mathrm{O}}$, which maintains binding to the $\mathrm{H}_{2} \mathrm{O}$ ligand, is lower in 


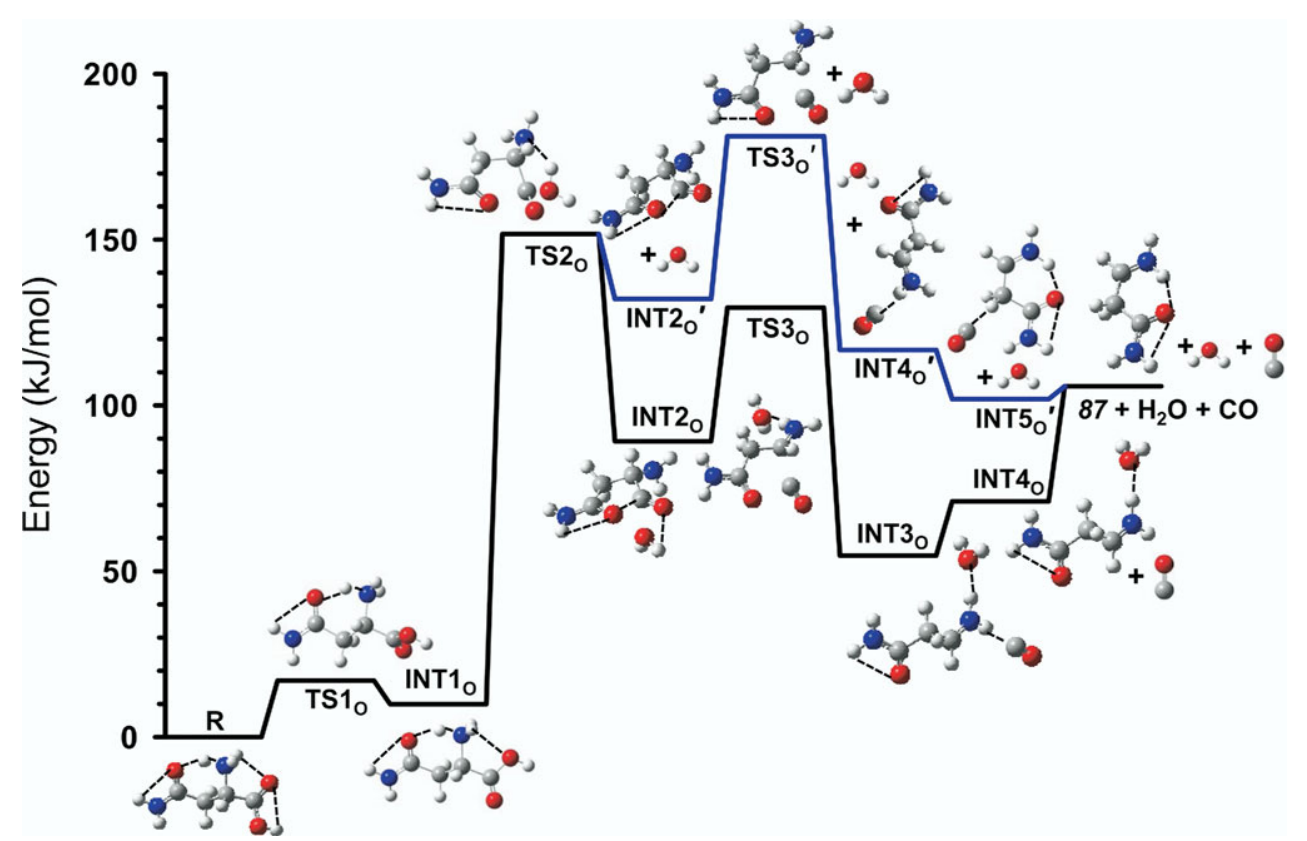

Figure 4. Reaction coordinate surface for $\left(\mathrm{H}_{2} \mathrm{O}+\mathrm{CO}\right)$ loss from $\mathrm{H}^{+}(\mathrm{Asn})$. Geometry optimizations and single point energies of each elementary step are determined at the B3LYP/6-311+G(d,p) level of theory and corrected for ZPE. In the higher energy pathway shown, water has already dissociated. Dashed lines indicate hydrogen bonds.

energy than $\mathrm{TS}_{\mathrm{O}}$ by $22.2 \mathrm{~kJ} / \mathrm{mol}$ and goes on to form $\mathrm{INT}_{\mathrm{O}}$, a bis-ligand complex of the $87 \mathrm{~m} / \mathrm{z}$ ion bound to $\mathrm{H}_{2} \mathrm{O}$ and CO. Alternatively, the loss of CO via $\mathrm{TS}_{\mathrm{O}^{\prime}}$, where the $\mathrm{H}_{2} \mathrm{O}$ ligand has already dissociated, requires $29.5 \mathrm{~kJ} / \mathrm{mol}$ more energy than $\mathrm{TS}_{\mathrm{O}}$. In the final steps of the reaction, the $\mathrm{INT}_{\mathrm{O}}$ complex sequentially dissociates into the reaction products, $87 \mathrm{~m} / z+\mathrm{H}_{2} \mathrm{O}+\mathrm{CO}$, or after passing over $\mathrm{TS}_{\mathrm{O}^{\prime}}{ }^{\prime}, \mathrm{INT} 44_{\mathrm{O}}{ }^{\prime}$, or $\mathrm{INT} 5{ }_{\mathrm{O}}{ }^{\prime}$ can lose $\mathrm{CO}$ to form the same products. Overall, once the energy of $\mathrm{TS}_{\mathrm{O}}$ is provided to the system, the loss of $\mathrm{H}_{2} \mathrm{O}+\mathrm{CO}$ can occur without further energy as long as the $\mathrm{H}_{2} \mathrm{O}$ product remains bound to the intermediate complexes, whereas if $\mathrm{H}_{2} \mathrm{O}$ is lost to form $115 \mathrm{~m} / z$, TS3 ${ }_{\mathrm{O}}^{\prime}$ must be overcome to subsequently lose $\mathrm{CO}$.

The pathway determined here for $\mathrm{CH}_{2} \mathrm{O}_{2}$ loss from $\mathrm{H}^{+}$(Asn), as involving loss of the combined elements $\left(\mathrm{H}_{2} \mathrm{O}+\mathrm{CO}\right)$, is qualitatively consistent with characterizations using quantum chemical methods for this process in protonated glycine $[18,19]$, small poly-glycyl peptides $[19,20]$, and other protonated amino acids [17]. However, because the amidic side-chain is directly involved in the rate-limiting $\mathrm{TS}_{\mathrm{O}}$, Figure 5, the mechanism in the protonated asparagine system must differ from those involving glycine. For example, $\left(\mathrm{H}_{2} \mathrm{O}+\mathrm{CO}\right)$ loss in the $\mathrm{H}^{+}$(Gly) system, which is similarly limited by a proton transfer between the hydroxyl and amino groups of the backbone $[18,19]$, cannot generate a cyclic intermediate to facilitate the reaction. In contrast, the poly-glycyl peptides do generate cyclic intermediates in this reaction pathway [20], although the identity of these species are necessarily distinct from that formed in the amidic $\mathrm{H}^{+}(\mathrm{Asn})$ system. Furthermore, the sug- gested transient formation of the 5-membered cyclic intermediate in $\mathrm{INT}_{\mathrm{O}}$ and the 115 product distinguishes it from the more global mechanism suggested by Rogalewicz et al. [17] for most protonated amino acids.

\section{Cross Section Modeling}

Equation 1 was used to analyze the thresholds for the competitive decomposition channels, which correspond to deamidation (represented as the sum of the $18+116+$ $74+88+44 \mathrm{~m} / z$ product cross sections $)$ and $\left(\mathrm{H}_{2} \mathrm{O}+\mathrm{CO}\right)$ loss $(115+87+60)$ from $\mathrm{H}^{+}$(Asn). The TS frequencies used for the cross section modeling are taken from our theoretical results and correspond to deamidation via $\mathrm{TS}_{\mathrm{N}}$ and $\left(\mathrm{H}_{2} \mathrm{O}+\mathrm{CO}\right)$ loss via TS2 $\mathrm{O}$. Using parameters given in Table 3, the data can be reproduced over extended energy and magnitude ranges as shown in Figure 5a. For a number of previous studies of competitive dissociations $[28,29,42,55]$, independent $\sigma_{0, j}$ values for each channel in the data modeling were used to reproduce the cross sections. The use of independent scaling factors is believed to compensate for neglected factors, such as reaction degeneracies, symmetry numbers of the reactant and product molecules, dipole moments of neutral products, and inaccurate frequency estimations (although all of these factors are included in the modeling to the best estimations available). In the present study, the use of independent $\sigma_{0, j}$ values to model the competitive cross sections required relative values exceeding five orders of magnitude to fit the data, for which it is difficult to provide a physical 

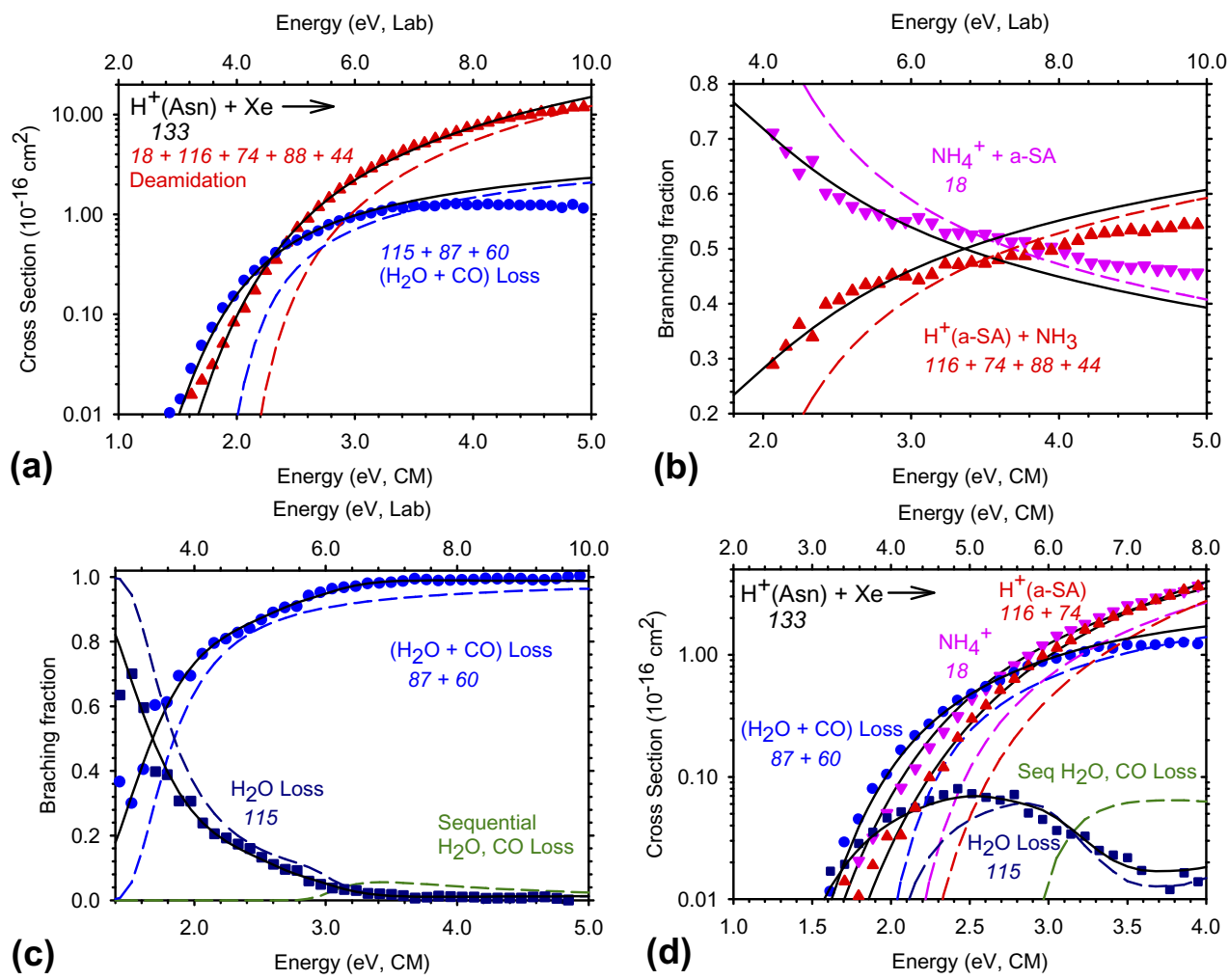

Figure 5. (a) Composite cross sections for deamidation and $\left(\mathrm{H}_{2} \mathrm{O}+\mathrm{CO}\right)$ loss from $\mathrm{H}^{+}(\mathrm{Asn})$ as a function of collision energy with Xe in the center-of-mass frame (lower $x$-axis) and the laboratory frame (upper $x$-axis). (b) Branching fractions for the $\mathrm{NH}_{4}{ }^{+}+$a-SA and $\mathrm{H}^{+}(\mathrm{a}-\mathrm{SA})+\mathrm{NH}_{3}$ pathways. (c) Branching fractions for the $\left(\mathrm{H}_{2} \mathrm{O}+\mathrm{CO}\right)$ loss, $\mathrm{H}_{2} \mathrm{O}$ loss, and sequential $\mathrm{H}_{2} \mathrm{O}, \mathrm{CO}$ loss pathways. (d) Cumulative fits for each of the primary reaction cross sections for $\mathrm{H}^{+}$(Asn) decomposition obtained by multiplying the cross sections of part a with the branching ratio models of parts $\mathrm{b}$ and $\mathrm{c}$. In each part, solid lines show the best fit to the data using the model of eq 1 convoluted over the neutral and ion kinetic and internal energy distributions. Dashed lines show the model cross sections in the absence of experimental kinetic energy broadening for reactions with an internal energy of $0 \mathrm{~K}$.

explanation. Alternatively, we have found that the data can also be accurately reproduced by loosening the low-frequency modes (arbitrarily chosen as below 500 $\mathrm{cm}^{-1} \equiv 720 \mathrm{~K}$ ) in the deamidation rate-limiting $\mathrm{TS}_{\mathrm{N}}$ by $50 \%$ while holding those for $\mathrm{TS}_{\mathrm{O}}$ constant. (In this regard, it is perhaps useful to note that the output of the Gaussian program warns that thermodynamic functions may be in error for vibrational frequencies under $625 \mathrm{~cm}^{-1} \equiv 900 \mathrm{~K}$, in large measure because such vibrations may no longer be treated accurately as harmonic at temperatures of interest. In the present system, at the lowest kinetic energy where deamidation products are first seen, about $1.7 \mathrm{eV}$, Figure 1, the average energy available to $\mathrm{TS}_{\mathrm{N}}$ corresponds to a temperature of about $1600 \pm 900 \mathrm{~K}$.) The need for scaling frequencies $<500 \mathrm{~cm}^{-1}$ indicates that the calculated harmonic frequencies for the deamidation $\mathrm{TS}_{\mathrm{N}}$ provide a somewhat too "tight" characterization of this channel relative to those for $\mathrm{TS}_{\mathrm{O}}$. Possibly this is because the contribution to the composite deamidation cross section from the $\mathrm{H}^{+}(\mathrm{a}-\mathrm{SA})+$ $\mathrm{NH}_{3}$ channel $(116+74+88+44)$, which has an endothermicity higher in energy than TS4 $4_{\mathrm{N}}$ as indicated by our theoretical results in Table 1, is therefore influenced by the loose TS leading to the $116 \mathrm{~m} / \mathrm{z}$ product.
Indeed, the $\mathrm{H}^{+}(\mathrm{a}-\mathrm{SA})$ and $\mathrm{NH}_{4}{ }^{+}$channels differ in their apparent thresholds, which is observable in comparing the 116 and $18 \mathrm{~m} / \mathrm{z}$ channels in Figure 1. To obtain thermochemical information for the $\mathrm{H}^{+}(\mathrm{a}-\mathrm{SA})$ and $\mathrm{NH}_{4}{ }^{+}$ channels separately, we modeled the branching ratio between the $\mathrm{H}^{+}(\mathrm{a}-\mathrm{SA})+\mathrm{NH}_{3}(116+74+88+44)$ and the $\mathrm{NH}_{4}{ }^{+}+$a-SA (18) pathways with eq 1 using loose PSL TSs for both $\mathrm{NH}_{4}^{+}+$a-SA and $\mathrm{H}^{+}(\mathrm{a}-\mathrm{SA})+\mathrm{NH}_{3}$. This analysis recognizes that although the total deamidation cross section shown in Figure 5 a is controlled by TS4 $_{N}$, the branching between these two channels is controlled by the subsequent decomposition of INT4 $4_{N}$, Figure 3 . As shown in Figure $5 b$, the branching ratio is accurately reproduced using the parameters given in Table 3, which includes tightening the PSL frequencies below $500 \mathrm{~cm}^{-1}$ in the $\mathrm{NH}_{4}{ }^{+}+$a-SA channel by $52 \%$. Good agreement between the threshold value for this channel and that obtained from analysis of the composite cross section, Figure $5 \mathrm{a}$, both $1.78 \mathrm{eV}$ (Table 3), is obtained. The need for tightening the low frequencies for this channel may indicate that this pathway is limited more by the tight $\mathrm{TS}_{\mathrm{N}}$ relative to the $\mathrm{H}^{+}(\mathrm{a}-\mathrm{SA})+\mathrm{NH}_{3}$ pathway. The reproduction of the data is excellent from threshold to about $3 \mathrm{eV}$, above which there are some deviations that can be correlated with the 
Table 3. Fitting parameters of eq 1, threshold energies at $0 \mathrm{~K}$, and entropies of activation at $1000 \mathrm{~K}^{\mathrm{a}}$

\begin{tabular}{|c|c|c|c|c|c|c|}
\hline Data & Reaction & $\begin{array}{l}\text { Frequency }^{\mathrm{b}} \\
\text { scaling }\end{array}$ & $\sigma_{0}$ & $n$ & $E_{\mathrm{o}}(\mathrm{eV})$ & $\begin{array}{c}\Delta \mathrm{S}^{\ddagger}{ }_{1000} \\
(\mathrm{~J} / \mathrm{K} / \mathrm{mol})\end{array}$ \\
\hline \multirow[t]{2}{*}{ Cross section } & $\left(\mathrm{H}_{2} \mathrm{O}+\mathrm{CO}\right)$ Loss $\mathrm{TS}_{\mathrm{O}}$ & 1.0 & $5.78(2.1)$ & $2.3(0.2)$ & $1.47(0.08)$ & $1(10)$ \\
\hline & Deamidation $\mathrm{TS}_{\mathrm{N}}$ & 0.50 & $5.78(2.1)$ & $2.3(0.2)$ & $1.78(0.08)$ & $93(8)^{c}$ \\
\hline \multirow[t]{2}{*}{ Branching fraction } & $\mathrm{NH}_{4}^{+}+\mathrm{a}-\mathrm{SA}$ & 1.52 & & $2.3(0.1)$ & $1.78(0.07)$ & $33(5)^{d}$ \\
\hline & $\mathrm{H}^{+}(\mathrm{a}-\mathrm{SA})+\mathrm{NH}_{3}$ & 1.0 & & $2.3(0.1)$ & $1.86(0.07)$ & $49(5)$ \\
\hline \multirow[t]{3}{*}{ Branching fraction } & $\left(\mathrm{H}_{2} \mathrm{O}+\mathrm{CO}\right)$ Loss $\mathrm{TS}_{\mathrm{O}}$ & 0.50 & & $0.1(0.1)$ & $1.34(0.05)$ & $103(10)^{\mathrm{e}}$ \\
\hline & $\mathrm{H}_{2} \mathrm{O}$ Loss INT2 ${ }_{\mathrm{O}}^{\prime}$ & 1.0 & & $0.1(0.1)$ & $1.31(0.05)$ & $99(8)$ \\
\hline & $\left(\mathrm{H}_{2} \mathrm{O}+\mathrm{CO}\right)$ Loss $\mathrm{TS} \mathrm{O}^{\prime}$ & $16(3)^{f}$ & & $0.1(0.1)$ & $2.78(0.12)$ & \\
\hline
\end{tabular}

ancertainties in parentheses.

bScaling factor applied to frequencies $<500 \mathrm{~cm}^{-1}$.

${ }^{\mathrm{c}} \Delta \mathrm{S}^{\ddagger}{ }_{1000}$ determined without TS frequency scaling is $19 \pm 1$.

${ }^{\mathrm{d}} \Delta \mathrm{S}^{\ddagger}{ }_{1000}$ determined without TS frequency scaling is $53 \pm 5$.

${ }^{\mathrm{e}} \Delta \mathrm{S}^{\ddagger}{ }_{1000}$ determined without TS frequency scaling is $17 \pm 1$.

${ }^{f} \mathrm{In}$ this case, the overall cross section was scaled by this factor, see text.

onset of the subsequent decompositions into the 74 and 88 $\mathrm{m} / \mathrm{z}$ product ions.

This type of treatment was further extended to describe the branching between the $\left(\mathrm{H}_{2} \mathrm{O}+\mathrm{CO}\right)$ loss $(87+60)$ and sequential $\mathrm{H}_{2} \mathrm{O}, \mathrm{CO}$ loss (115) channels, Figure 5c. Here, theory (Figure 5) indicates that the thresholds for the two pathways both occur at $\mathrm{TS}_{\mathrm{O}}$, however, the 115 channel subsequently loses $\mathrm{CO}$ to form 87, explaining why its cross section decreases sharply compared to the $(87+60)$ channel, Figure 1 . In this case, the molecular parameters for fitting the branching ratio correspond to an energized molecule of $\mathrm{INT}_{\mathrm{O}}$ (with an absolute energy determined by theory) combined with a tight TS for $\left(\mathrm{H}_{2} \mathrm{O}+\mathrm{CO}\right)$ loss to form $87+60\left(\mathrm{TS}_{\mathrm{O}}\right)$ and a loose PSL TS for loss of $\mathrm{H}_{2} \mathrm{O}$ to form 115 (INT2 $\left.{ }_{\mathrm{O}}^{\prime}\right)$, with the latter channel also being able to sequentially dissociate by passing over the tight TS $3_{\mathrm{O}}$ '. To adequately reproduce the branching ratio up to about $3 \mathrm{eV}, \mathrm{TS}_{\mathrm{O}}$ needed to be looser (frequencies below $500 \mathrm{~cm}^{-1}$ scaled by 0.5 ) than that calculated directly from theory (or equivalently INT2 ${ }_{\mathrm{O}}$ ' could be tighter). (Notably scaling factors of 0.4 or 0.6 could not be used and still reproduce the data accurately.) These results provide the $0 \mathrm{~K}$ energies of $\mathrm{TS}_{\mathrm{O}}$, leading to $\left(\mathrm{H}_{2} \mathrm{O}+\mathrm{CO}\right)$ loss after passing over TS2 ${ }_{\mathrm{O}}$, and INT2 ${ }^{\prime}{ }^{\prime}$, resulting in loss of $\mathrm{H}_{2} \mathrm{O}$ after passing over $\mathrm{TS}_{\mathrm{O}}$, Table 3. Reproduction of the branching ratio is very good up to about $3 \mathrm{eV}$, Figure $5 \mathrm{c}$. If the theoretically calculated molecular parameters of $\mathrm{TS}_{\mathrm{O}^{\prime}}$, the sequential channel for CO loss from 115, are used without alteration, this sequential dissociation channel has little effect on the branching ratio. However, if this channel is scaled upwards appreciably (factors of 13-18), then the decline in the 115 branching fraction (and concomitant increase in the $87+60$ channel) can be reproduced with fidelity, Figure $5 \mathrm{c}$. As the threshold energy obtained for this sequential dissociation is well above the theoretical values for the tight $\mathrm{TS}_{\mathrm{O}}$ ' (see below), we believe that the observed sequential dissociation does not correspond to $\mathrm{TS}_{\mathrm{O}^{\prime}}$, but is probably associated with an entropically favored process located at higher energies on the potential energy surface.
Overall, we obtain thresholds from the competitive cross sections for the lowest energy deamidation pathway (formation of $\mathrm{NH}_{4}{ }^{+}+$a-SA) and for $\left(\mathrm{H}_{2} \mathrm{O}+\right.$ $\mathrm{CO})$ loss from $\mathrm{H}^{+}$(Asn). From the deamidation branching ratio fit, we obtain thresholds for generation of both the $\mathrm{NH}_{4}{ }^{+}+\mathrm{a}-\mathrm{SA}$ and $\mathrm{H}^{+}(\mathrm{a}-\mathrm{SA})+\mathrm{NH}_{3}$ products, where the former matches that obtained from the competitive cross section modeling (as the appearance of this channel is limited by $\mathrm{TS}_{\mathrm{N}}$ ). Additionally, from the $(87+60)$ versus 115 ratio modeling, we obtain energies for intermediates involved in both concerted $\left(\mathrm{H}_{2} \mathrm{O}+\mathrm{CO}\right)$ loss $\left(\mathrm{TS}_{\mathrm{O}}\right)$ and sequential $\mathrm{H}_{2} \mathrm{O}, \mathrm{CO}$ loss $\left(\mathrm{INT}_{\mathrm{O}}{ }^{\prime}\right.$ ) from $\mathrm{H}^{+}$(Asn), where the appearance of both channels is limited by $\mathrm{TS}_{\mathrm{O}}$. The threshold energies obtained are summarized in Table 3, along with values of $\Delta S^{\ddagger}{ }_{1000}$, the entropy of activation at $1000 \mathrm{~K}$ for each reaction pathway modeled here. Figure $5 \mathrm{~d}$ shows the cumulative fits for each of the four primary reaction channels for $\mathrm{H}^{+}$(Asn) decomposition modeled here, determined by multiplying the model cross sections of Figure $5 \mathrm{a}$ and the branching fraction models of Figure $5 b$ and $c$ for each channel.

\section{Theoretical Results for Alternate $\left(\mathrm{H}_{2} \mathrm{O}+\mathrm{CO}\right)$ Loss Rate-Limiting TSs}

Because the mechanism for $\left(\mathrm{H}_{2} \mathrm{O}+\mathrm{CO}\right)$ loss from $\mathrm{H}^{+}$(Asn) has not been characterized in detail previously, we investigated several alternative mechanistic pathways for this reaction. Figure 6 and Table 4 provide six alternative rate-limiting TSs for $\mathrm{H}_{2} \mathrm{O}$-loss from $\mathrm{H}^{+}$(Asn), all having $\left(\mathrm{Asn}^{+}-\mathrm{OH}\right)\left(\mathrm{H}_{2} \mathrm{O}\right)$ structures and designating the sites where water binds to $\left(\mathrm{Asn}^{+}-\mathrm{OH}\right)$ in brackets with $\mathrm{B}$ and $\mathrm{S}$ subscripts distinguishing backbone and side-chain sites, respectively.

The lowest energy alternate TS, $\left[\mathrm{CO}_{S}, \mathrm{CO}_{\mathrm{B}}\right] \mathrm{TS}$, is comparable in energy to $\mathrm{TS}_{\mathrm{O}}$ (lying $3 \mathrm{~kJ} / \mathrm{mol}$ lower, 5 $\mathrm{kJ} / \mathrm{mol}$ higher, and equal in energy at the B3LYP, B3P86, and MP2(full) levels, respectively). When used in the data analysis, the agreement between the exper- 


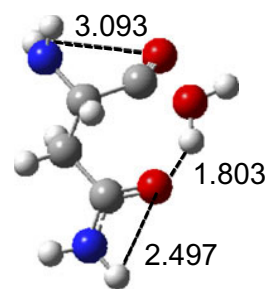

$\left[\mathrm{CO}_{\mathrm{S}}, \mathrm{CO}_{\mathrm{B}}\right] \mathrm{TS}$

$(150,164,146)$

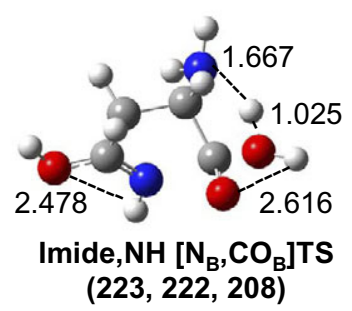

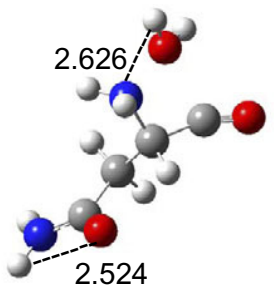

$\left[\mathrm{N}_{\mathrm{B}}, \mathrm{CO}_{\mathrm{B}}\right] \mathrm{TS}$

$(187,206,173)$

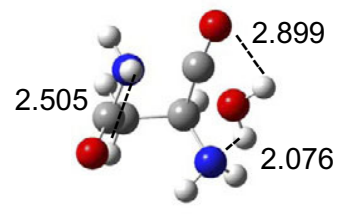

Imide, $\mathrm{NH}_{2}\left[\mathrm{~N}_{\mathrm{B}}, \mathrm{CO}_{\mathrm{B}}\right] \mathrm{TS}$

$(229,240,212)$

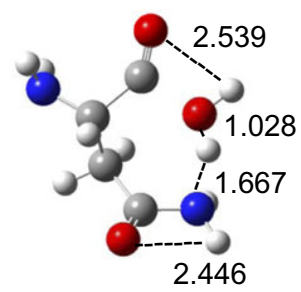

$\left[\mathrm{N}_{\mathrm{S}}, \mathrm{CO}_{\mathrm{B}}\right] \mathrm{TS}$

$(203,213,197)$

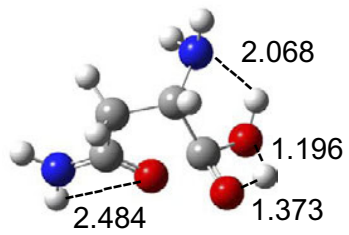

Gemdiol $\left[\mathrm{N}_{\mathrm{B}}, \mathrm{CO}_{\mathrm{B}}\right] \mathrm{TS}$

$(273,258,272)$

Figure 6. Alternative transition-state structures for $\left(\mathrm{H}_{2} \mathrm{O}+\mathrm{CO}\right)$ loss from $\mathrm{H}^{+}($Asn $)$calculated at B3LYP / 6-311 $+\mathrm{G}(\mathrm{d}, \mathrm{p})$ level. Hydrogen bond lengths are shown in Å. Energies $(\mathrm{kJ} / \mathrm{mol})$ from Table 4 are indicated at the B3LYP, B3P86, and MP2(full) levels of theory.

imental threshold and the theoretical energy is comparable to that for $\mathrm{TS}_{\mathrm{O}}$, but the vibrational frequencies for this TS required significant scaling (either by independent channel scaling about $\sim 10^{-5}$, or by tightening all TS frequencies below $500 \mathrm{~cm}^{-1}$ by a factor of 3) to reproduce the data. On this basis, $\left[\mathrm{CO}_{\mathrm{S}}, \mathrm{CO}_{\mathrm{B}}\right] \mathrm{TS}$ was ruled out as the best TS for $\left(\mathrm{H}_{2} \mathrm{O}+\mathrm{CO}\right)$ loss, although it is a plausible alternative to $\mathrm{TS}_{\mathrm{O}}$. The detailed pathway for forming $\left[\mathrm{CO}_{\mathrm{S}}, \mathrm{CO}_{\mathrm{B}}\right] \mathrm{TS}$ from ground state reactants including all local minima was explored, starting from $\mathrm{H}^{+}(\mathrm{Asn})[\mathrm{CO}, \mathrm{CO}] \mathrm{ctgt}$, Figure 2, rotation of the carboxylic acid group forms a $\mathrm{H}^{+}(\mathrm{Asn})\left[\mathrm{CO}_{\mathrm{S}}, \mathrm{OH}\right]$ structure in which the proton bridges the side-chain carbonyl and the hydroxyl group. This intermediate lies about $70 \mathrm{~kJ} / \mathrm{mol}$ above ground state reactants. This configuration has an orientation that allows the $\mathrm{H}_{2} \mathrm{O}$ ligand to dissociate while interacting favorably with the side-chain carbonyl in $\left[\mathrm{CO}_{\mathrm{S}}, \mathrm{CO}_{\mathrm{B}}\right] \mathrm{TS}$. Once past the transition-state, INT2 $2_{\mathrm{O}}$ is again formed.

Table 4. Alternative $\mathrm{H}^{+}$(Asn) $\left(\mathrm{H}_{2} \mathrm{O}+\mathrm{CO}\right)$ loss transition state energies $(\mathrm{kJ} / \mathrm{mol})^{\mathrm{a}}$

\begin{tabular}{lccc}
\hline \multicolumn{1}{c}{$\mathrm{H}^{+}$(Asn) } & B3LYP & B3P86 & MP2(full) \\
\hline \hline TS2 $_{\mathrm{O}}$ & 154.3 & 158.7 & 146.2 \\
$\left(\mathrm{Asn}^{+}-\mathrm{OH}\right)\left(\mathrm{H}_{2} \mathrm{O}\right)\left[\mathrm{CO}_{\mathrm{S}}, \mathrm{CO}_{\mathrm{B}}\right] \mathrm{TS}$ & 150.3 & 163.6 & 146.3 \\
$\left(\mathrm{Asn}^{+}-\mathrm{OH}\right)\left(\mathrm{H}_{2} \mathrm{O}\right)\left[\mathrm{N}_{\mathrm{B}}, \mathrm{CO}_{\mathrm{B}}\right] \mathrm{TS}$ & 186.8 & 206.1 & 173.4 \\
$\left(\mathrm{Asn}^{+} \mathrm{OH}\right)\left(\mathrm{H}_{2} \mathrm{O}\right)\left[\mathrm{N}_{\mathrm{S}}, \mathrm{CO}_{\mathrm{B}}\right] \mathrm{TS}$ & 203.4 & 213.3 & 196.5 \\
$\left(\mathrm{Asn}^{+}-\mathrm{OH}\right)\left(\mathrm{H}_{2} \mathrm{O}\right) \mathrm{imide}_{\mathrm{NH}} \mathrm{NH}$ & 223.0 & 221.5 & 208.1 \\
$\quad\left[\mathrm{~N}_{\mathrm{B}}, \mathrm{CO} \mathrm{B}_{\mathrm{B}}\right] \mathrm{TS}$ & & & \\
$\left(\mathrm{Asn}^{+}-\mathrm{OH}\right)\left(\mathrm{H}_{2} \mathrm{O}\right)$ imide, $\mathrm{NH}_{2}$ & 229.1 & 240.0 & 212.3 \\
$\quad\left[\mathrm{~N}_{\mathrm{B}}, \mathrm{CO} \mathrm{B}_{\mathrm{B}}\right] \mathrm{TS}$ & & & \\
$\left(\mathrm{Asn}^{+}-\mathrm{OH}\right)\left(\mathrm{H}_{2} \mathrm{O}\right)$ gemdiol & 272.6 & 257.6 & 271.7 \\
$\quad\left[\mathrm{~N}_{\mathrm{B}}, \mathrm{CO}_{\mathrm{B}}\right] \mathrm{TS}$ & & & \\
\hline
\end{tabular}

${ }^{a}$ Calculations performed at the stated level of theory using a $6-311+G(2 d, 2 p)$ basis set with geometries calculated at B3LYP/6-311+ $\mathrm{G}(\mathrm{d}, \mathrm{p})$ level. Energies relative to $\mathrm{H}^{+}(\mathrm{Asn})[\mathrm{N}, \mathrm{CO}] \mathrm{tgtt}$ including zero point corrections.
The next TS structure shown in Figure 6, $\left[\mathrm{N}_{\mathrm{B}}, \mathrm{CO}_{\mathrm{B}}\right] \mathrm{TS}$, transfers a hydrogen from the backbone amino group to the backbone carboxylic acid $\mathrm{OH}$ group starting from $\mathrm{H}^{+}$(Asn) $[\mathrm{N}, \mathrm{CO}] \mathrm{tttt}, \mathrm{INT} 1_{\mathrm{O}}$, and then proceeding to an acyclic $\mathrm{NH}_{2}(\mathrm{CO}) \mathrm{CH}_{2} \mathrm{CH}\left(\mathrm{NH}_{2}\right) \mathrm{CO}^{+}\left(\mathrm{H}_{2} \mathrm{O}\right)$ intermediate, where the water binds to the latter $\mathrm{NH}_{2}$ group. As the side chain is no longer involved in stabilizing the transition state, this pathway is analogous to the ratelimiting TS for $\left(\mathrm{H}_{2} \mathrm{O}+\mathrm{CO}\right)$ loss for smaller amino acids reported $[18,19]$. Therefore, the detailed PES for forming $\left[\mathrm{N}_{\mathrm{B}}, \mathrm{CO}_{\mathrm{B}}\right] \mathrm{TS}$ from the ground state reactants was explored in detail (provided in Figure S1 and Table S1 of the Supporting Information, which can be found in the electronic version of this article). The energy of $\left[\mathrm{N}_{\mathrm{B}}, \mathrm{CO}_{\mathrm{B}}\right] \mathrm{TS}$ lies $27-47 \mathrm{~kJ} / \mathrm{mol}$ higher in energy than $\mathrm{TS}_{\mathrm{O}}$ (Table 4) and therefore is clearly not the most favorable pathway for $\left(\mathrm{H}_{2} \mathrm{O}+\mathrm{CO}\right)$ loss from $\mathrm{H}^{+}$(Asn). The calculated energy of this TS relative to the ground state reactant complex is slightly higher $(12-14 \mathrm{~kJ} / \mathrm{mol})$ than the comparable TS found for loss of $\left(\mathrm{H}_{2} \mathrm{O}+\mathrm{CO}\right)$ from $\mathrm{H}^{+}$(Gly) at the B3LYP/6-31G(d) and MP2/6$31 G(d)$ levels $[18,19]$. This small difference is attributable to the more stable $\mathrm{H}^{+}$(Asn) starting complex, which has more extensive hydrogen bonding than $\mathrm{H}^{+}$(Gly), and possibly to different basis sets used.

All other alternative TSs in Figure 6 and Table 4 lie over $50 \mathrm{~kJ} / \mathrm{mol}$ higher in energy than $\mathrm{TS}_{\mathrm{O}}$. An analogue to $\left[\mathrm{CO}_{\mathrm{S}}, \mathrm{CO}_{\mathrm{B}}\right] \mathrm{TS},\left[\mathrm{N}_{\mathrm{S}}, \mathrm{CO}_{\mathrm{B}}\right] \mathrm{TS}$ differs from the former by participation of the side-chain amide in the active site, rather than the side-chain carbonyl oxygen. Thus, this transition state connects $\mathrm{H}^{+}$(Asn) [N,N]tgtg with an intermediate similar to $\mathrm{INT}_{\mathrm{O}}$, but where the water is hydrogen bonded to the amino group rather than to the carbonyl. This results in an increase in energy of the TS over TS2 $\mathrm{O}$ of $49-53 \mathrm{~kJ} / \mathrm{mol}$. Additionally, two TSs that result in imide ring formation were investigated, where 
the active-site side-chain nitrogen is either mono- or di-hydrogenated. The energy difference between these conformers is only $4-18 \mathrm{~kJ} / \mathrm{mol}$. Imide, $\mathrm{NH}\left[\mathrm{N}_{\mathrm{B}}, \mathrm{CO}_{\mathrm{B}}\right] \mathrm{TS}$ connects an $\mathrm{H}^{+}$(Asn) intermediate protonated at the sidechain carbonyl with a succinimide protonated at one of the carbonyls with the water hydrogen bonded to the amino group. Imide, $\mathrm{NH}_{2}\left[\mathrm{~N}_{\mathrm{B}}, \mathrm{CO}_{\mathrm{B}}\right] \mathrm{TS}$ connects $\mathrm{H}^{+}$(Asn) $[\mathrm{N}, \mathrm{CO}] \mathrm{ttt}$ with a succinimide product protonated at the imide site, where the water is also hydrogen bonded. Lastly, an alternate conformer that starts at $\mathrm{H}^{+}(\mathrm{Asn})[\mathrm{N}, \mathrm{CO}]$ tgtt and leads to the same heterocyclic ring structure of $\mathrm{INT}_{\mathrm{O}}$ was investigated. Gemdiol $\left[\mathrm{N}_{\mathrm{B}}, \mathrm{CO}_{\mathrm{B}}\right] \mathrm{TS}$ differs from $\mathrm{TS}_{\mathrm{O}}$ by proton transfer between the backbone carboxylic acid group oxygen atoms instead of between the amino nitrogen and carboxylic acid $\mathrm{OH}$ group, resulting in an energy increase of $99-126 \mathrm{~kJ} / \mathrm{mol}$ from $\mathrm{TS}_{\mathrm{O}}$. In light of these results, we conclude that $\mathrm{TS}_{\mathrm{O}}$ in Figure 4 and Table 4 is the most viable rate-limiting TS for $\left(\mathrm{H}_{2} \mathrm{O}+\right.$ CO) loss from $\mathrm{H}^{+}$(Asn).

\section{Conversion from 0 to $298 \mathrm{~K}$ and Excited Conformers}

Conversion from $0 \mathrm{~K}$ reaction energies to $298 \mathrm{~K}$ reaction enthalpies and free energies is accomplished using the rigid rotor/harmonic oscillator approximation with rotational constants and vibrational frequencies calculated at the B3LYP/6-311+G(d,p) level. These $\Delta \mathrm{H}_{298}$ and $\Delta G_{298}$ values along with the conversion factors and $0 \mathrm{~K}$ enthalpies measured here are reported in Table 5 . The uncertainties listed are determined by scaling all the vibrational frequencies by $\pm 10 \%$. Pronounced differences are observed between molecular conversion constants of reactions involving tight versus loose TSs. For the tight TSs, $\mathrm{TS} 2_{\mathrm{O}}, \mathrm{TS} 4_{\mathrm{N}}$, and $\mathrm{TS} 3_{\mathrm{O}}, \mathrm{T} \Delta \mathrm{S}$ is near zero and much smaller than $\mathrm{T} \Delta \mathrm{S}$ for the loose TS reaction of $\mathrm{H}^{+}$(a-SA) $+\mathrm{NH}_{3}$ formation and $\mathrm{H}_{2} \mathrm{O}$ loss, Table 5, as expected. As a consequence of the entropic terms, the $\Delta \mathrm{G}_{298}$ values for the primary tight TSs lie within $1-5 \mathrm{~kJ} / \mathrm{mol}$ of the $\Delta \mathrm{H}_{0}$ values for each reaction, whereas $\Delta \mathrm{G}_{298}$ for the loose TS reactions lie at energies 30-40 kJ/mol smaller than $\Delta \mathrm{H}_{0}$. Similarly, the sequential reaction of $\mathrm{H}_{2} \mathrm{O}, \mathrm{CO}$ loss with the rate limiting $\mathrm{TS}_{\mathrm{O}}{ }^{\prime}$ has a $\Delta \mathrm{G}_{298}$ value $43 \mathrm{~kJ} / \mathrm{mol}$ smaller than $\Delta \mathrm{H}_{0}$ because the correction includes free $\mathrm{H}_{2} \mathrm{O}$ as a reaction product.

We also calculated the $\Delta G_{298}$ values for the lowest energy structures of the $\mathrm{H}^{+}$(Asn) system. The relative $\Delta \mathrm{G}_{298}$ excitation energies are comparable to the analogous differences in the $\Delta \mathrm{H}_{0}$ values, Table 1 . The theoretical reaction energies discussed below are all calculated relative to the GS $\mathrm{H}^{+}$(Asn) reactant, $\mathrm{H}^{+}$(Asn) $[\mathrm{N}, \mathrm{CO}]$ tgtt for our DFT methods and $\mathrm{H}^{+}(\mathrm{Asn})[\mathrm{N}, \mathrm{CO}] \mathrm{tcgt}$ for our MP2(full) calculations. For the $\mathrm{H}^{+}$(Asn) system, possibly the complexes formed experimentally in the source region at thermal energies may consist of multiple low-energy conformers. Although no obvious evidence for multiple conformers is found experimentally, the sensitivity of TCID experiments to low-energy species is not particularly acute. On the basis of the $\Delta G_{298}$ values of all conformers, an equilibrium population of the $\mathrm{H}^{+}$(Asn) molecule in the room-temperature ion source is dominated by the two low-energy structures, $[\mathrm{N}, \mathrm{CO}]$ tgtt and $[\mathrm{N}, \mathrm{CO}] \mathrm{tcgt}$. These species are calculated to comprise $34 \%-71 \%$ and $27 \%-62 \%$ of the total population, respectively. The next two lowest energy excited conformers, $[\mathrm{N}, \mathrm{CO}] \mathrm{ttgt}$ and $\mathrm{tttt}$, are calculated to comprise only $0.9 \%-3.7 \%$ and $0.4 \%-0.7 \%$ of the total population. Confirmation of these computational results comes from an infrared multiphoton dissociation (IRMPD) action spectroscopy study that investigates the gas-phase conformations of cationized asparagine complexes [56]. The IRMPD spectrum of $\mathrm{H}^{+}$(Asn) is fully accounted for by a combination of the $[\mathrm{N}, \mathrm{CO}]$ tgtt and $[\mathrm{N}, \mathrm{CO}] \mathrm{tcgt}$ structures both being populated. Because the energy differences between these two conformers are small at all levels of theory considered, to have both conformations populated does not affect the thermochemistry obtained experimentally within our stated experimental uncertainties. To verify this conclusion, we analyzed the data using the molecular parameters of both the $[\mathrm{N}, \mathrm{CO}]$ tgtt and $[\mathrm{N}, \mathrm{CO}] \mathrm{tcgt}$ structures. The threshold energies change by less than $1 \mathrm{~kJ} / \mathrm{mol}$ in all cases, an effect that is included in the experimental uncertainties listed in the tables.

Table 5. Enthalpies and free energies of reaction at 0 and $298 \mathrm{~K}(\mathrm{~kJ} / \mathrm{mol})^{\mathrm{a}}$

\begin{tabular}{llcrrrr}
\hline Reactant & \multicolumn{1}{c}{ Reaction } & $\Delta \mathrm{H}_{0}{ }^{\mathrm{b}}$ & $\Delta \mathrm{H}_{298}-\Delta \mathrm{H}_{0}{ }^{\mathrm{c}}$ & $\Delta \mathrm{H}_{298}$ & $\mathrm{~T}_{298} \mathrm{~S}^{\mathrm{c}}$ & $\Delta \mathrm{G}_{298}$ \\
\hline \hline $\mathrm{H}^{+}$(Asn) & $\left(\mathrm{H}_{2} \mathrm{O}+\mathrm{CO}\right)$ Loss TS2 & $141(6)$ & $0.8(0.1)$ & $142(6)$ & $-1.2(0.1)$ & $143(6)$ \\
& Deamidation TS4 & $172(8)$ & $2.5(0.3)$ & $175(8)$ & $4.7(0.5)$ & $170(8)$ \\
& & & $11.0(1.0)$ & $183(8)$ & $25.0(2.2)$ & $158(8)$ \\
& & $179(7)$ & $4.4(0.4)$ & $183(7)$ & $43.4(4.4)$ & $140(8)$ \\
& $\mathrm{H}^{+}(\mathrm{a}-\mathrm{SA})+\mathrm{NH}_{3}$ & $129(5)$ & $4.3(0.1)$ & $133(5)$ & $6.3(0.1)$ & $127(5)$ \\
& $\left(\mathrm{H}_{2} \mathrm{O}+\mathrm{CO}\right)$ Loss TS3 & & $11.2(0.4)$ & $140(5)$ & $30.1(0.5)$ & $110(5)$ \\
& & $126(5)$ & $0.9(0.4)$ & $127(5)$ & $34.5(1.3)$ & $92(6)$ \\
& & $268(12)$ & $7.9(0.8)$ & $276(12)$ & $51.2(5.2)$ & $225(13)$ \\
& $\mathrm{H}_{2} \mathrm{O}$ Loss INT2 ${ }^{\prime}$ & & &
\end{tabular}

ancertainties in parentheses.

bexperimental values from Table 3.

${ }^{c}$ Calculated using standard formulas and molecular constants calculated at the B3LYP/6-311+G(d,p) level. Values in italics utilize the scaled frequencies used to reproduce the magnitude of the data (see text and Table 3). 


\section{Discussion}

\section{Comparison of Experimental and Theoretical Values}

Experimental threshold energies for decomposition of $\mathrm{H}^{+}$(Asn) using TCID experiments with a guided ion beam mass spectrometer are compared with calculated quantum chemical reaction energies in Table 6 . The agreement between experiment and theory for these reactions is quite satisfactory. The range of theoretically determined values agree with the experimental thresholds within experimental uncertainty in all cases except TS3 ${ }_{\mathrm{O}}$ ', where the discrepancy suggests that the observed high-energy process must correspond to another pathway, as noted above. This quantitative agreement, along with our qualitative analyses, clearly identify the rate-limiting transition states found theoretically, TS4 $4_{\mathrm{N}}$ in Figure 3 for deamidation, and $\mathrm{TS}_{\mathrm{O}}$ and $\mathrm{TS}_{\mathrm{O}}$ in Figure 5 for $\left(\mathrm{H}_{2} \mathrm{O}+\mathrm{CO}\right)$ loss from $\mathrm{H}^{+}$(Asn), as the most likely rate-limiting steps for these reactions. A comprehensive evaluation of our theoretical numbers show that all three levels of theory considered provide results in reasonable agreement with experiment, with mean absolute deviations (MADs) from experimentally determined values of $8-13 \mathrm{~kJ} / \mathrm{mol}$. These variations are comparable to our experimental uncertainties for the primary $\mathrm{H}^{+}$(Asn) decomposition reactions.

\section{Comparison to Deamidation of $\mathrm{Na}^{+}($Asn $)$}

Heaton and Armentrout [15] have previously investigated deamidation in the $\mathrm{Na}^{+}$(Asn) system. Here the rate-limiting transition-state was characterized as involving three molecular characteristics: a hydrogen transfer to form ammonia, ring-closure to form a-SA, and loss of the $\mathrm{NH}_{3}$. The molecular details of the rate-limiting transition-state for $\mathrm{Na}^{+}$(Asn) deamidation are comparable to those for $\mathrm{TS}_{\mathrm{N}}$, with $\mathrm{Na}^{+}$replacing the uppermost bridging proton of the structure shown in Figure 3. One distinction is that in the $\mathrm{Na}^{+}$(Asn) system, ammonia is formed by proton transfer at the rate-limiting TS, whereas in the present system, this proton transfer occurs before the rate-limiting transition-state. This is reflected in the additive charge distribution of the ammonia ligand in $\mathrm{TS}_{\mathrm{N}}$, which is close to neutral at $+0.1(\mathrm{~N}=-0.70,3 \mathrm{H}=$ $3 \times \sim 0.27$ ), whereas in the rate-limiting TS for $\mathrm{Na}^{+}$(Asn) deamidation, the incipient $\mathrm{NH}_{3}$ leaving group has an overall charge of $+0.5(\mathrm{~N}=-0.36,3 \mathrm{H}=$ $\sim 0.30$ ). Interestingly, the barrier for deamidation in the sodiated Asn system $(155 \pm 8 \mathrm{~kJ} / \mathrm{mol})$ lies at an energy $17 \pm 11 \mathrm{~kJ} / \mathrm{mol}$ lower than that for the protonated system. Overall, these comparisons indicate that the charge carrier, $\mathrm{H}^{+}$versus $\mathrm{Na}^{+}$, and its localization (higher in the $\mathrm{Na}^{+}$case) do not greatly influence the mechanism or energetics of this degradation process.

\section{Conclusions}

The kinetic energy dependence of the collision-induced dissociation of $\mathrm{H}^{+}$(Asn) with $\mathrm{Xe}$ is examined in a guided ion beam mass spectrometer. The threshold energies at $0 \mathrm{~K}$ for $\mathrm{H}^{+}$(Asn) deamidation and $\left(\mathrm{H}_{2} \mathrm{O}+\right.$ $\mathrm{CO})$ loss are determined after consideration of the effects of reactant internal energy, multiple collisions with $\mathrm{Xe}$, lifetime effects [41], and competition among channels [42]. The rate-limiting TS for deamidation, $\mathrm{TS}_{\mathrm{N}}$, involves concerted succinic ring closure and ammonia loss. Furthermore, the branching behavior of $\mathrm{H}^{+}$(Asn) deamidation to $\mathrm{NH}_{4}{ }^{+}+$a-SA and $\mathrm{H}^{+}$(a-SA) $+\mathrm{NH}_{3}$ is comprehensively described as involving contributions from both $\mathrm{TS}_{\mathrm{N}}$ and the loose TS of the more endothermic $\mathrm{H}^{+}(\mathrm{a}-\mathrm{SA})+\mathrm{NH}_{3}$ pathway. The rate-limiting TS for $\left(\mathrm{H}_{2} \mathrm{O}+\mathrm{CO}\right)$ loss, $\mathrm{TS}_{\mathrm{O}}$, involves $\mathrm{H}_{2} \mathrm{O}$ loss facilitated by the side chain to again form a cyclic intermediate, which can subsequently lose $\mathrm{CO}$ without additional energy being provided to the system so long as the $\mathrm{H}_{2} \mathrm{O}$ ligand remains bound to the complex. In order for the system to sequentially lose $\mathrm{H}_{2} \mathrm{O}$ followed by $\mathrm{CO}$, a higher energy loose TS becomes the rate-limiting TS for $\mathrm{CO}$ loss. The experimental results are compared to detailed quantum chemical calculations. The experimental threshold energies are in good agreement with calculations at several levels of theory. The thresholds reported here for $\mathrm{H}^{+}$(Asn) deamidation and $\left(\mathrm{H}_{2} \mathrm{O}+\mathrm{CO}\right)$ loss constitute the first experimental gasphase measurement of these reactions and one of the first detailed characterizations of the potential energy

Table 6. Experimental and theoretical reaction energies $(\mathrm{kJ} / \mathrm{mol})$

\begin{tabular}{|c|c|c|c|c|c|}
\hline Reactant & Reaction & Experiment $^{\mathrm{a}}$ & B3LYPb & B3P86 $^{b}$ & MP2(full) $)^{b}$ \\
\hline $\mathrm{H}^{+}($Asn $)$ & $\begin{array}{l}\left(\mathrm{H}_{2} \mathrm{O}+\mathrm{CO}\right) \text { Loss; } \mathrm{TS}_{\mathrm{O}} \\
\mathrm{NH}_{4}{ }^{+}+\mathrm{a}-\mathrm{SA} ; \mathrm{TS}{ }_{\mathrm{N}} \\
\mathrm{H}^{+}(\mathrm{a}-\mathrm{SA})+\mathrm{NH}_{3} \\
\left(\mathrm{H}_{2} \mathrm{O}+\mathrm{CO}\right) \text { Loss; TS3 }_{\mathrm{O}} \\
\mathrm{H}_{2} \mathrm{O} \text { Loss; INT2 } \mathrm{O}^{\prime} \\
\left(\mathrm{H}_{2} \mathrm{O}+\mathrm{CO}\right) \text { Loss; } \mathrm{TS}_{\mathrm{O}}{ }^{\prime} \\
\mathrm{MAD}^{\mathrm{e}}\end{array}$ & $\begin{array}{l}141(6) \\
172(5)^{\mathrm{c}} \\
179(7) \\
129(5) \\
126(5) \\
268(12)\end{array}$ & $\begin{array}{l}154 \\
162 \\
168^{d} \\
133 \\
128 \\
180 \\
8(5)\end{array}$ & $\begin{array}{l}159 \\
171 \\
176^{\mathrm{d}} \\
162 \\
137 \\
213 \\
13(13)\end{array}$ & $\begin{array}{c}146 \\
160 \\
173[165]^{\mathrm{d}} \\
144 \\
136 \\
198 \\
10(4)[11(4)]\end{array}$ \\
\hline
\end{tabular}

apresent experimental values from Table 3. Uncertainties in parentheses.

${ }^{b}$ Calculations performed at the stated level of theory using a $6-311+G(2 d, 2 p)$ basis set with geometries calculated at B3LYP/6-311+ G(d,p) level, zero point energy corrections included.

${ }^{\mathrm{c}}$ Average of thresholds obtained from the cross section and branching ratio fits.

${ }^{\mathrm{d}}$ Counterpoise corrected (not appropriate for tight TSs).

'Mean absolute deviation from experimental values excluding $\mathrm{TS}_{\mathrm{O}} \mathrm{O}$. 
surface for decomposition of a protonated amino acid. The experimental results supported by theoretical calculations identify the elementary steps of the two main reaction pathways, their rate-limiting transition states, and higher-order energetic features, which dictate the threshold energy of the reactions. Compared with previous results on the deamidation of $\mathrm{Na}^{+}$(Asn), the present results find a very similar rate-limiting transition-state and a slightly higher activation energy, indicating that the charge carrier is not a key factor in determining the mechanism or energetics of this degradation process.

\section{Acknowledgments}

The authors acknowledge support for this work by the National Science Foundation, grant CHE-0748790. The authors also gratefully acknowledge a grant of computer time from the Center for High Performance Computing at the University of Utah.

\section{Appendix A. Supplementary Material}

Supplementary material associated with this article may be found in the online version at doi:10.1016/ j.jasms.2008.12.027.

\section{References}

1. Robinson, N. E.; Robinson, A. B. Molecular Clocks. Proc. Natl. Acad. Sci. U.S.A. 2001, 98, 944-949.

2. Clarke, S. Aging as War Between Chemical and Biochemical Processes: Protein Methylation and the Recognition of Age-Damaged Proteins for Repair. Aging Res. Rev. 2003, 2, 263-285.

3. Shimizu, T.; Watanabe, A.; Ogawara, M.; Mori, H.; Shirasawa, T. Isoaspartate Formation and Neurodegeneration in Alzheimer's Disease. Arch. Biochem. Biophys. 2000, 381, 225-234.

4. Shimizu, T.; Fukuda, H.; Murayama, S.; Izumiyama, N.; Shirasawa, T. Isoaspartate Formation at Position 23 of Amyloid $\beta$-Peptide Enhanced Fibril Formation and Deposited onto Senile Plaques and Vascular Aamyloids in Alzheimer's Disease. J. Neurosci. Res. 2002, 70, 451-461.

5. Robinson, N. E.; Robinson, A. B. Prediction of Primary Structure Deamidation Rates of Asparaginyl and Glutaminyl Peptides Through Steric and Catalytic Effects. J. Pept. Res. 2004, 63, 437-448.

6. Konuklar, F. A.; Aviyente, V.; Sen, T. Z.; Bahar, I. Modeling the Deamidation of Asparagine Residues Via Succinimide Intermediates. J. Mol. Model. 2001, 7, 147-160.

7. Patel, K.; Borchardt, R. T. Chemical Pathways of Peptide Degradation. II. Kinetics of Deamidation of an Asparaginyl Residue in a Model Hexapeptide. Pharm. Res. 1990, 7, 703-711.

8. Tyler-Cross, R.; Schirch, V. Effects of Amino Acid Sequence, Buffers, and Ionic Strength on the Rate and Mechanism of Deamidation of Asparagine Residues in Small Peptides. J. Biol. Chem. 1991, 266, 22549 22556.

9. Song, Y.; Schowen, R. L.; Borchardt, R. T.; Topp, E. M. Effect of 'pH' on the Rate of Asparagine Deamidation in Polymeric Formulations: ' $\mathrm{pH}$ 'rate profile. J. Pharm. Sci. 2001, 90, 141-156.

10. Capasso, S.; Mazzarella, L.; Sica, F.; Zagari, A.; Salvadori, S. Kinetics and Mechanism of Succinimide Ring Formation in the Deamidation Process of Asparagine Residues. J. Chem. Soc. Perkin Trans. 1993, 2, 679-682.

11. Peters, B.; Trout, B. L. Asparagine Deamidation: $\mathrm{pH}-$ Dependent Mechanism from Density Functional Theory. Biochemistry 2006, 45, 53845392.

12. Cournoyer, J. J.; Pittman, J. L.; Ivleva, V. B.; Fallows, E.; Waskell, L.; Costello, C. E.; O'Connor, P. B. Deamidation: Differentiation of Aspartyl from Isoaspartyl Products in Peptides by Electron Capture Dissociation. Protein Sci. 2005, 14, 452-463.

13. Cournoyer, J. J.; Lin, C.; O'Connor, P. B. Detecting Deamidation Products in Proteins by Electron Capture Dissociation. Anal. Chem. 2006, $78,1264-1271$.

14. Cournoyer, J. J.; Lin, C.; Bowman, M. J.; O'Connor, P. B. Quantitating the Relative Abundance of Isoaspartyl Residues in Deamidated Proteins by Electron Capture Dissociation. J. Am. Soc. Mass Spectrom. 2007, 18, $48-56$
15. Heaton, A. L.; Armentrout, P. B. Thermodynamics and Mechanism of the Deamidation of Sodium-Bound Asparagine. J. Am. Chem. Soc. 2008, 130, 10227-10232.

16. Dookeran, N. N.; Yalcin, T.; Harrison, A. G. Fragmentation Reactions of Protonated $\alpha$-Amino Acids J. Mass Spectrom. 1996, 31, 500-508.

17. Rogalewicz, F.; Hoppilliard, Y.; Ohanessian, G. Fragmentation Mechanisms of $\alpha$-Amino Acids Protonated Under Electrospray Ionization: A Collision Activation and $\mathrm{Ab}$ Initio Theoretical Study. Int. J. Mass Spectrom. 2000, 195/196, 565-590.

18. O'Hair, R. A. J.; Broughton, P. S.; Styles, M. L.; Frink, B. T.; Hadad, C. M The Fragmentation Pathways of Protonated Glycine: A Computational Study. J. Am. Soc. Mass Spectrom. 2000, 11, 687-696.

19. Klassen, J. S.; Kebarle, P. Collision-Induced Dissociation Threshold Energies of Protonated Glycine, Glycinamide, and Some Related Small Peptides and Peptide Amino Amides. J. Am. Chem. Soc. 1997, 119, 6552-6563.

20. El Aribi, H.; Rodriquez, C. F.; Almeida, D. R. P.; Ling, Y.; Mak W. W.-N.; Hopkinson, A. C.; Siu, K. W. M. Elucidation of Fragmentation Mechanisms of Protonated Peptide Ions and Their Products: A Case Study on Glycylglycylglycine Using Density Functional Theory and Threshold Collision-Induced Dissociation. J. Am. Chem. Soc. 2003, 125, 9229-9236.

21. Ervin, K. M.; Armentrout, P. B. Translational Energy Dependence of $\mathrm{Ar}^{+}+\mathrm{XY} \rightarrow \mathrm{ArX}^{+}+\mathrm{Y}\left(\mathrm{XY}=\mathrm{H}_{2}, \mathrm{D}_{2}, \mathrm{HD}\right)$ from Thermal to $30 \mathrm{eV}$ c.m. J. Chem. Phys. 1985, 83, 166-189.

22. Muntean, F. Armentrout, P. B. Guided Ion Beam Study of CollisionInduced Dissociation Dynamics: Integral and Differential Cross Sections. J. Chem. Phys. 2001, 115, 1213-1228.

23. Moision, R. M.; Armentrout, P. B. An Electrospray Ionization Source for Thermochemical Investigation with the Guided Ion Beam Mass Spectrometer. J. Am. Soc. Mass Spectrom. 2007, 18, 1124-1134.

24. Moision, R. M.; Armentrout, P. B. An Experimental and Theoretical Dissection of Sodium Cation/Glycine Interactions. J. Phys. Chem. A 2002, 106, 10350-10362.

25. Heaton, A. L.; Moision, R. M.; Armentrout, P. B. Experimental and Theoretical Studies of Sodium Cation Interactions with the Acidic Amino Acids and Their Amide Derivatives. J. Phys. Chem. A 2008, 112, 3319-3327.

26. Heaton, A. L.; Armentrout, P. B. Experimental and Theoretical Studies of Potassium Cation Interactions with the Acidic Amino Acids and Their Amide Derivatives. J. Phys. Chem. B 2008, 112, 12056-12065.

27. Kim, T.; Tolmachev, A. V.; Harkewicz, R.; Prior, D. C.; Anderson, G.; Udseth, H. R.; Smith, R. D. Design and Implementation of a New Electrodynamic Ion Funnel. Anal. Chem. 2000, 72, 2247-2255.

28. Ye, S. J.; Moision, R. M.; Armentrout, P. B. Sequential Bond Energies of Water to Sodium Glycine Cation. Int. J. Mass Spectrom. 2005, 240, 233-248.

29. Heaton, A. L.; Ye, S. J.; Armentrout, P. B. Experimental and Theoretical Studies of Sodium Cation Complexes of the Deamidation and Dehydration Products of Asparagine, Glutamine, Aspartic Acid, and Glutamic Acid. J. Phys. Chem. A 2008, 112, 3328-3338.

30. Ye, S. J.; Armentrout, P. B. Absolute Measurements of Alkali Metal Cation Interactions with a Simple Dipeptide and Tripeptide. J. Phys. Chem. A 2008, 112, 3587-3596.

31. Teloy, E.; Gerlich, D. Integral cross sections for ion-molecule reactions. I. The guided beam technique. Chem. Phys. 1974, 4, 417-427.

32. Gerlich, D. Inhomogeneous RF Fields: A Versatile Tool for the Study of Processes with Slow Ions. Adv. Chem. Phys. 1992, 82, 1-176.

33. Aristov, N.; Armentrout, P. B. Collision Induced Dissociation of Vanadium Monoxide Ion. J. Phys. Chem. 1986, 90, 5135-5140.

34. Dalleska, N. F.; Honma, K.; Sunderlin, L. S.; Armentrout, P. B. Solvation of Transition Metal Ions by Water. Sequential Binding Energies of $\mathrm{M}^{+}\left(\mathrm{H}_{2} \mathrm{O}\right) \times(\mathrm{x}=1-4)$ for $\mathrm{M}=\mathrm{Ti}-\mathrm{Cu}$ Determined by Collision-Induced Dissociation. J. Am. Chem. Soc. 1994, 116, 3519-3528.

35. Daly, N. R. Scintillation Type Mass Spectrometer Ion Detector. Rev. Sci. Instrum. 1960, 31, 264-267.

36. Beyer, T. S.; Swinehart, D. F. Algorithm 448: Number of MultiplyRestricted Partitions. Commun. ACM 1973, 16, 379.

37. Stein, S. E.; Rabinovitch, B. S. Accurate Evaluation of Internal Energy Level Sums and Densities Including Anharmonic Oscillators and Hindered Rotors. J. Chem. Phys. 1973, 58, 2438-2445.

38. Stein, S. E.; Rabinovitch, B. S. On the Use of Exact State Counting Methods in RRKM Rate Calculations. Chem. Phys. Lett. 1977, 49, 183-188.

39. Gilbert, R. G.; Smith, S. C. Theory of Unimolecular and Recombination Reactions; Blackwell Scientific: London, 1990, 1-356.

40. Robinson, P. J.; Holbrook, K. A. Unimolecular Reactions; Wiley Interscience: New York, 1972, 1-371.

41. Rodgers, M. T.; Ervin, K. M.; Armentrout, P. B. Statistical Modeling of Collision-Induced Dissociation Thresholds. J. Chem. Phys. 1997, 106, 4499-4508.

42. Rodgers, M. T.; Armentrout, P. B. Statistical Modeling of Competitive Threshold Collision-Induced Dissociation. J. Chem. Phys. 1998, 109, 1787-1800.

43. Hales, D. A.; Lian, L.; Armentrout, P. B. Collision-Induced Dissociation of $\mathrm{Nb}_{\mathrm{n}}{ }^{+}(n=2-11)$ : Bond Energies and Dissociation Pathways. Int. J. Mass Spectrom. Ion Processes 1990, 102, 269-301.

44. Frisch, M. J.; Trucks, G. W.; Schlegel, H. B.; Scuseria, G. E.; Robb, M. A.; Cheeseman, J. R.; Montgomery, J. A. Jr.; Vreven, T.; Kudin, K. N.; Burant, J. C.; Millam, J. M.; Iyengar, S. S.; Tomasi, J.; Barone, V.; Mennucci, B.; Cossi, M.; Scalmani, G.; Rega, N.; Petersson, G. A.; 
Nakatsuji, H.; Hada, M.; Ehara, M.; Toyota, K.; Fukuda, R.; Hasegawa, J.; Ishida, M.; Nakajima, T.; Honda, Y.; Kitao, O.; Nakai, H.; Klene, M.; Li, X.; Knox, J. E.; Hratchian, H. P.; Cross, J. B.; Adamo, C.; Jaramillo, J.; Gomperts, R.; Stratmann, R. E.; Yazyev, O.; Austin, A. J.; Cammi, R.; Pomelli, C.; Ochterski, J. W.; Ayala, P. Y.; Morokuma, K.; Voth, G. A.; Salvador, P.; Dannenberg, J. J.; Zakrzewski, V. G.; Dapprich, S.; Daniels, A. D.; Strain, M. C.: Farkas, O.; Malick, D. K.; Rabuck, A. D. Raghavachari, K.; Foresman, J. B.; Ortiz, J. V.; Cui, Q.; Baboul, A. G.; Clifford, S.; Cioslowski, J.; Stefanov, B. B.; Liu, G.; Liashenko, A.; Piskorz, P.; Komaromi, I.; Martin, R. L.; Fox, D. J.; Keith, T.; Al-Laham, M. A.; Peng, C. Y.; Nanayakkara, A.; Challacombe, M.; Gill, P. M. W. Johnson, B.; Chen, W.; Wong, M. W.; Gonzalez, C.; Pople, J. A. Gaussian 03, Revision B.02; Gaussian, Inc.: Pittsburgh, PA, 2003.

45. Moision, R. M.; Armentrout, P. B. The Special Five-Membered Ring of Proline: An Experimental and Theoretical Investigation of Alkali Metal Cation Interactions with Proline and Its Four- and Six-Membered Ring Analogues. J. Phys. Chem. A 2006, 110, 3933-3946.

46. Montgomery, J. A. Jr.; Frisch, M. J.; Ochterski, J. W.; Petersson, G. A. A Complete Basis Set Model Chemistry. VI. Use of Density Functional Geometries and Frequencies. J. Chem. Phys. 1999, 110, 2822-2827.

47. Boys, S. F.; Bernardi, R. The Calculation of Small Molecular Interactions by the Differences of Separate Total Energies. Some Procedures with Reduced Errors. Molec. Phys. 1970, 19, 553-566.

48. van Duijneveldt, F. B.; van Duijneveldt de Rijdt, J. G. C. M.; van Lenthe, J. H. State of the Art in Counterpoise Theory. Chem. Rev. 1994, 94, 1873-1885.
49. Armentrout, P. B.; Rodgers, M. T. An Absolute Sodium Cation Affinity Scale: Threshold Collision-Induced Dissociation Experiments and $\mathrm{Ab}$ Initio Theory. J. Phys. Chem. A 2000, 104, 2238-2247.

50. Wong, C. H. S.; Siu, F. M.; Ma, N. L.; Tsang, C. W. A Theoretical Study of Potassium Cation-Glycine ( $\mathrm{K}^{+}$-Gly) Interactions. J. Mol. Struct. (Theochem.) 2002, 588, 9-16.

51. Feller, D.; Glendening, E. D.; Woon, M. W.; Feyereisen, J. An Extended Basis Set Ab Initio Study of Alkali Metal Cation-Water Clusters. J. Chem. Phys. 1995, 103, 3526-3542

52. Feller, D. A Complete Basis Set Estimate of Cation- $\pi$ Bond Strengths: $\mathrm{Na}^{+}$(Ethylene) and $\mathrm{Na}^{+}$(Benzene). Chem. Phys. Lett. 2000, 322, 543-548.

53. Hoyau, S.; Norrman, K.; McMahon, T. B.; Ohanessian, G. A Quantitative Basis for a Scale of $\mathrm{Na}^{+}$Affinities of Organic and Small Biological Molecules in the Gas Phase. J. Am. Chem. Soc. 1999, 121, 8864-8875.

54. McMahon, T. B.; Ohanessian, G. An Experimental and Ab Initio Study of the Nature of the Binding in Gas-Phase Complexes of Sodium Ions. Chem. Eur. J. 2000, 6, 2931-2941.

55. Amicangelo, J. C.; Armentrout, P. B. Relative and Absolute Bond Dissociation Energies of Sodium Cation Complexes Determined Using Competitive Collision-Induced Dissociation Experiments. Int. J. Mass Spectrom. 2001, 212, 301-325.

56. Heaton, A. L.; Bowman, V.; Armentrout, P. B.; Oomens, J.; Steill, J. D. Infrared Multiphoton Dissociation Spectroscopy of Cationized Asparagine: Effects of Alkali-Metal Cation Size on Gas-Phase Conformation (work in progress). 